\title{
The Socio-cultural and Historical Basis for the Double Rite of Passage in the Nomiya Church in Kenya
}

\author{
Samuel Otieno Sudhe ${ }^{1}$, Sussy Gumo ${ }^{1, *}$, Crispinous Iteyo ${ }^{2}$ \\ ${ }^{1}$ Department of Religion, Theology and Philosophy, Maseno University, Kenya \\ ${ }^{2}$ Department of Peace and Conflict Studies, Masinde Muliro University of Science \&Technology, Kenya
}

Copyright (C) 2015 by authors, all rights reserved. Authors agree that this article remains permanently open access under the terms of the Creative Commons Attribution License 4.0 International License

\begin{abstract}
This paper explores the socio-cultural and historical background that gives rise to the unique practice of the double rite of passage in the Nomiya Church (NC) in Kenya. The NC as the first African Initiated Church (AIC) in Kenya started among the Luo people, a community that traditionally did not practice circumcision. Circumcision and baptism as religious rites of initiation are simultaneously performed on the male infant on the eighth day after birth. The double rite of passage is evidently a reversal of the decision of the first Church Council of AD 49 at Jerusalem (Acts 15) which settled for baptism rather than circumcision as the Christian initiation rite. The conceptual framework here called 'appropriation dialogue' is the biblical concept of covenant. Covenant entails mutual reciprocity whereby God seeks relationship with human beings, who respond in obedience as they appropriate the gifts from God. The NC theology is grounded on God's calling of Prophet Johana Owalo. The pillars of the NC are in her rejection of the doctrine of Trinity and in her denial of the divinity of Christ. The NC embraces African practices like polygamy and levirate marriage. In the $\mathrm{NC}$ worship are several aspects of Islamic worship. This study has endeavoured to answer the question on the continued relevance of circumcision to the theology of the NC if baptism in Christianity is the sign of the new covenant. The double rite of passage is at the core of the NC theology.
\end{abstract}

Keywords Covenant, Nomiya Church, Double Rite of Passage, Baptism, Circumcision, Prophet Owalo

\section{Introduction}

The Nomiya Church (NC) stands as the very first African Initiated Church (AIC) in Kenya in 1912 at a time when the missionary enterprise was just settling to work. Missionary work in Kenya was inaugurated in the middle of the $19^{\text {th }}$ century. Western Kenya the cradle of the NC was only reached towards the end of the $19^{\text {th }}$ century and the early part of the $20^{\text {th }}$ century. Nthamburi, $[1,170]$ observes that the missionaries strived to introduce 'Christian culture' to replace the 'heathen culture' Right from the onset it was inevitable that the missionary endeavor would clash with the local cultures. Nthamburi, $[1,170]$ argues that when the missionaries thought that the Christian culture had triumphed within the African Christian, the heathen culture to their dismay dared to rear its ugly head. Taylor, [2, xvii] concurs that the missionary sponsored Christianity failed to penetrate the African psyche. Suppressing and crushing the African culture was not to be. Mbiti, [3,1-2] rightly observes that the African religion permeates into all departments of life and further that a person cannot detach himself from the religion of his group for to do so is to be severed from his roots and his context of security. The end result according to Taylor [2, xvii] was that the spread of Christianity was tempered by the unprecedented proliferation of thousands of independent churches, most of which were established by Africans to challenge missionary ecclesiology and theology. Obviously then the Christianity that was spreading across the African continent was a blend of several world views brought together.

This is affirmed by C.S.Song in his suggestion that when the Gospel is introduced within a culture it affects the said culture while undergoing change itself. According to C.S.Song the Gospel is "transposed" like a sweet melody into a new key. This dynamic interaction brings about change in human institutions, creating new values while changing the hearts of people (Song cited in Mugambi, $[4,1]$ ). The Nomiya Church (NC) is a Christian denomination which like many AIC's has chosen one Old Testament practice or another or an African heritage practice or many and which they have so blended together with Judeo-Christian practices in order to yield a practice that is authentically African. Prophet Owalo, the founder of the NC in 1907, was shown into the presence of God and from this experience he recognized and challenged several ills in the Anglican Church as well as the Catholic Church in which he worshipped. He later moved to Islam. The NC therefore is uniquely a Christian denomination that carries and practices 
several Islamic concepts.

The double rite of passage of circumcision and baptism in the $\mathrm{NC}$ is unique in Christianity and also in Judaism. Circumcision in Judaism shares a lot with circumcision practiced in the NC but is not done in the context of baptism. On the other hand, baptism is the only rite in most Christian denominations that consider the circumcision rite in the Jewish context obsolete having been replaced by baptism. Baptism and circumcision are performed simultaneously on the eighth day after birth. on the male infant. For the NC the double rite of passage is a blend of the Luo culture, the Jewish culture and the European enterprise influence that has given rise to a practice so unique that most of Christendom will find strange while the Jews may not agree with it though it stems from the Old Testament (Hebraic) prescription.

For the NC the fact that the rites of circumcision and baptism have now become a tradition they are understood as rite of admission into the body of Christ and a sign of the seal of the covenant relationship between God and his people. The double rite of passage affirms the divine initiative whereby God moves graciously to man declaring his desire for fellowship. Consequently God and man come into a mutual relationship; a relationship best referred to as 'appropriation dialogue' because it entails mutual reciprocity

The Luo culture just like the Jewish culture has one concurrence that is in their patriarchy. Every sphere of the day-to-day life promoted male superiority and dominance and women seem to be systematically disadvantaged and subordinated. The areas of disparity may be seen in the few cited cases: The double rite of passage from the outset seems to favor men over women. Women are not allowed circumcision or any other rite that would entail bloodshed. Baptism of female infants has been fixed on the fourteenth day for those infants whose parents are full communicant members. This disparity in the NC continued albeit the swelling demand for the recognition of the role and contribution of women in the church and throughout the society at large the world over.

Being a Christian in Kenya today means being a follower of the many strands in the mainline churches, the charismatic, the independent churches or the Catholic Church. These various faces of Christianity together give the country the distinction of being a Christian state.

\subsection{Conceptual Framework}

This study is based on the biblical concept of covenant. The relationship between members of the community of faith and God is best represented in the concept of covenant (Brueggemann, [5,65]). The theme of covenant in the Bible is an expression of peoplehood. The conceptual framework of covenant in this study is best summarized as 'appropriation dialogue' as it entails mutual reciprocity whereby God moves to establish a relationship with human beings who in return respond in obedience. God's election of human beings to be covenant partners corresponds to God's eternal love. Covenant, therefore, is a promissory relationship that is grounded on God's grace and faithfulness (Brueggemann, [5,44-45]). The text of Ex 19:3b-8 best describes this relationship:

Now if you obey me fully and keep my covenant, then out of all nations you will be my treasured possession. Although the whole earth is mine you will be for me a kingdom of priests and a holy nation.[6]

God confers upon Israel the status of royalty (a kingdom of priests and a holy nation), if only they will obey him (Levenson [7,31]). The bilateral relationship between the adherents and the supernatural is manifested in the rites of passage that are the human response of obedience. Brueggemann [5:65]) argues that in covenant making YHWH signs as the God of Israel and Israel submits in obedience to the commands of YHWH. He notes that this relationship of command and obedience is definitional of Israel and is reflected in the covenant formula and promise "I will be your God and you will be my people" (Ex. 6:7[8]; Jer. $11: 4 ; 24: 7 ; \quad 30: 22[9] ;$ Ezek. 11:20; 14:11[10]). The Abrahamic covenant is the first instance where the human beings enjoined in the covenant are to carry on their body the sign of the covenant (Gen 17:7-11)[11].

Circumcision was understood as a seal of God's choice of Abraham and his descendants. Dosick [12,286] says that circumcision became and endures as the sign of the covenant between God and the Jewish people. The shedding of blood was a symbol of God's chosen people being united to God himself by a blood covenant ([O'Donovan, 13,235]).The concept of circumcision progressively assumes a different understanding as an event with spiritual overtones much more than a surgical operation on the flesh of the body. This seems to be what the Bible refers to as circumcision of the heart (Deut. 10:6[14], Col. 2:11[15]; Jer. 4: 4, 9:26[16]) and it means being united in heart and soul to the Lord (O’Donovan, [13,236]).

The Old Testament seems to point to a new covenant that will be written in people's hearts (Jer. 31:31[17]). In the institution of Holy Communion, Jesus seems to refer to his body and blood as symbols of a new covenant (Mat 26:26-28 [18]). The command of Jesus to the new community is captured in the Great Commission (Matt 28:19-20 [19]). Entering the new covenant, according to Paul, means being baptized into Christ's death and being raised with him into new life (Rom 6:11 c.f. Col. 2:12 [20]).

In the New Testament circumcision of the heart seems to imply that the ritual of physical circumcision has been replaced with the ritual of water baptism as the sign of membership of God's covenant community (1Cor.7:19 [21]; Rom.6:1-4 [22]; Col. 2:11-12 [23]; Acts 2:38[24]; O'Donovan, [13, 236]; Marshall et al [25,121]). Further, Marshall et al $[25,121]$ notes that the circumcision made without hands also referred to as the circumcision of the heart is what mattered most. This circumcision of the heart, he says, is effected by the gift of the Spirit and it has rendered circumcision unnecessary (Gal 3:3; 5:3-5[26]); Rom 
2:28-29[27]). Marshall et al [25]concludes that the evidence of the Spirit in a person's life serves as sign and seal of the new covenant just as circumcision served for the old covenant (2Cor.3:3-6 [28]; Jer. 31:31-34 [29]; 2 Cor.1:22[30]). The human response seems to be tied to repentance and is said to be sealed by baptism (Acts 2:38 [31]; Mk. 16:16[32] ).

God's covenant in the New Testament proclaims the realization of the new covenant in Jesus Christ (Migliore, $[33,293])$. Christ's once-for-all sacrifice is God's covenant that opens human beings to blessings and responsibilities of life in the new community that serves and glorifies God. The Church is called to be a community of love and service in which all participate in an exchange of gifts given by the "gifting God" (Migliore, [33,268]). The 'appropriation dialogue' brings God and man into a covenant partnership. Human beings are consecrated and purified through baptism and circumcision for a mutual relationship with the holy God (Lev. 11:44[34]). Faithful partnership yields blessings while violation of the covenant leads to God's wrath (curses) (Deut. 30:15-19[35]).

This bilateral relationship is best demonstrated in the triangular schema outlined here below with God at the very top as He relates to man, and man to man at the bottom. Man's response yields a community that God loves and describes as Joga (my people) and which adores God and refers to him as Nyasachwa (our God). 'Appropriation dialogue' as the inclusive conceptual framework assisted this study in investigating the origins and significance of the double rite of passage in the NC. The double rite of passage can be viewed in this context as an effort by her members to participate in and appropriate the gifts from God.

\section{Literature Review}

The NC is not only the first of the AICs founded in Kenya but uniquely the only one that practices circumcision and baptism simultaneously performed on the male infant on the eighth day of its birth and on adult males on their admission. On the other hand female infants are only baptized on the fourteenth day while adult females are baptized on their admission. Literature review in this study analyzes the gap in the objective: To establish the socio-cultural and historical basis for the double rite of passage in the NC.

A number of scholars have written about the origins and history of the Nomiya Church as one of the AICs. These authors have written from different motivations and persuasions. Ndeda notes that the rapid increase in the number of independent churches in Kenya has attracted the attention of many scholars (Ndeda [36,1]). The growth of these churches is the most serious phenomenon of Christianity in modern Africa (Mbiti [3, 232]). This trend has been described in the scholarly world as the shift of the center of gravity of Christianity from the west to the south (Mwaura cited in Mugambi and Getui [37, 102]).

The AICs in Kenya have their origin in the turbulent period of the country's history dominated by missionary activities and British colonization (Mwaura in Mugambi and Getui [37,103]). Several factors were responsible for the emergence, proliferation and continuation of these churches: African traditional culture and religion; missionary paternalism and colonial legacy among others (Nthamburi $[38,16]$; Mbiti $[3,233])$. However, the foundational issue seems to be an attempt by African people to indigenize the Christian faith, interpret it and apply it in ways that give Christianity an African identity.

The missionary efforts had concentrated in two areas of dense settlement now known as Central and Western Provinces (Wipper, [39]; Nthamburi, [38,16]).The majority of the indigenous churches are located in Western Kenya among the Luo and the Luhyia communities (Nthamburi, $[38,16]$; Isichei, [40,243]). Consequently, the proliferation of indigenous Churches took place in an area in which the missions were well received and where the response of mission teaching was positive (Nthamburi, $[38,16]$ ).

The reason for this good reception among the Luo people (a major group in Western Kenya) could be attributed to the shared belief in a supreme being who is the source of all livelihoods. The Luo believed in the existence of a supreme being (Nyasaye) (Ogutu, [41]; Achieng, [42). Nyasaye is the center that holds everything together; the beginning of all things and in Him all living things owe their being. The Luo culture holds that the entire universe is God's creation and that human persons were given the responsibility of taking care of all resources from God (Ongong'a, [43]).

The Nomiya Church (NC), which was the first AIC in Kenya was founded among the Luo by Johana Owalo in 1912 (Mwaura in Mugambi and Getui [37,103]; Wipper, [39]; Nthamburi, [38, 17]; Ndeda, [36,5]). Being the very first AIC in Kenya, the question this study sought to answer was what aspects of this complex social, theological and political background influenced Owalo to found a church with the unique practice of the double rite of passage.

\subsection{The Socio-cultural and Historical Basis for the Double Rite of Passage in the NC}

The beginnings and development of circumcision and baptism in the $\mathrm{NC}$ will be traced in literature that deal with the rise and spread of the AICs, as well as those that present circumcision and baptism as initiation rites. Available literature on Johana Owalo seems to support political causes as the reason behind the formation of the $\mathrm{NC}$ (Odinga [44:68-69]; Ogot [45,262]; Lonsdale [46]; Wipper [39]). According to Ndeda [36], Owalo must have been involved possibly as a porter when the construction of the railway was approaching Kisumu sometime before 1900. He then proceeded to Mombasa where he worked for Judge Morrison. It is here that he supposedly encountered God through many visions and revelations that convinced him of his call. On March 1, 1907 Owalo claimed to have been taken to the first, second and third heaven by the spirit (Kitap Ligangla [47], Ndeda [36]). 
Owalo's heavenly excursion claim is full of graphic details of his interaction with the deity and the instructions there from. In the first heaven, which is the abode of men he saw that the Arabs, the Jews and the Luo were the only people allowed in for they had prophetic representatives; the Europeans (the Pope inclusive), the Goans and the Indian Bunyans were locked out because they failed to meet the conditions (Kitap Ligangla [47]; Ndeda [36]). God the Father instructed Owalo to acknowledge that he was the one and only one worthy of worship. Judge Morrison deterred Owalo from starting his movement until he had acquired adequate education (Ogot [45]).

Owalo later moved to CMS School in Nairobi, Church of Scotland in Kikuyu and then to Ojola joining the Catholic mission where his teachings were seen to be inimical to the Catholic faith and he was sent away. Owalo believed strongly that Jesus was not of the same substance as God (but God's messenger) and at the same time he rejected monogamy as a European idea (Ndeda, [36]). He also rejected the Catholic doctrine of purgatory and the belief in the supremacy and infallibility of the Pope and the intercession of the saints and particularly that of Mary (Ndeda [36]). Finally he ended up at Maseno as a teacher, where he was expelled for his beliefs (Ogot, [45]). He left Maseno to start his mission to the Luo that he named Nomiya Luo Mission (NLM). Consequently, Ndeda [36] argues that the two most immediate causes for the founding of NLM (later renamed NC) were the fact that Owalo was called by God in March 1907 and the fact that he was expelled from Maseno prematurely.

Owalo must have been circumcised during his time with the Muslims in Kisumu or Mombasa (Ndeda [36]). Owalo's circumcision was novel as the Luo rite of initiation entailed the removal of six lower teeth of both boys and girls at puberty. Boys and girls were required to visit Janak (the initiator) who using a special skill removed six of the lower teeth in a painful and bloody operation.

The basis of circumcision may be traced in the details of the heavenly excursion claim by Owalo. The idea of circumcision on the eighth day may also be connected with the fact that in this heavenly vision Owalo saw the Arabs, the Jews and the Luos as the only people allowed in for they had prophetic representatives. Baptism may also be traced to Owalo's denominational tour in this early period of Christianity in Nyanza. Unlike circumcision that is to be performed on a specific date after birth, Christian denominations that practice baptism are not strict as to a specific day in which it has to be performed. The reason for the simultaneous initiation rites on the male infant on the eighth day after birth and the reason for female infant baptism on the fourteenth day is the gap this study seeks to bridge.

\subsection{Beginnings and Development of Circumcision}

According to the book of Genesis, circumcision was first practiced by the patriarchs and it involved all males of the household (Gen.17 [48]). The Genesis narrative has two important foundations: that all male within the household were to be circumcised and secondly that from that time hence forth male infant circumcision was to take place on the eighth day after birth. Circumcision became the most critical distinguishing mark that separated the Israelites from the surrounding peoples. McGrath [49] also notes that circumcision was the rite laid down by the Old Testament covenant community. The child was born into a community and circumcision was a sign of belonging to this community (Marshall et al, [25,204]).

The OT understands circumcision as a religious rite performed on male children of Jews on the eighth day after birth (Gen. 17:12 [50]; Lev.12:3[51]). This rite was enjoined upon Abraham and his descendants as a "token of the covenant" between him and all the generations thereafter. This covenant covered slaves born in the household or not (O'Donovan [13,235]). The concept of circumcision was deeply rooted in the minds of the Hebrew people as a means to national consecration and purification (Gen. 17:10-17[52], Gen. 21:4 [53], Lev. 12:3[51]). Circumcision was later integrated into Mosaic system in connection with the Passover (Ex. 12:44[54]). Aliens were expected to undergo circumcision before they could be allowed to partake the covenant feast of the Passover (Ex. 12: 48[55]) or even to marry into the Jewish community (Gen. 34:14-16 [56]). Non-Israelites, especially the Philistines, were often described as uncircumcised (1 Sam. 14:6; 21:4 [57]). Uncircumcision was viewed as a blemish which could only be removed through circumcision.

The discussion of circumcision in the NT finds its focus in the Pauline letters. Paul in the epistle to the Galatians notes that circumcision is not required of Gentile believers. Paul argues that the Gentiles belong to the people of God by virtue of their faith in Christ. He says that the cross is the way of entering the covenant (Marshall et al $[25,204]$; O'Donovan $[13,234-5])$. Circumcision is a foundation feature of NT Judaism. It occasioned the Judaistic controversies of the apostolic period. Circumcision of proselytes was the occasion of controversies between Hellenistic Jews and Palestinian Jews (Hebrews). These Judaizing teachers (a section of Jewish Christians in the early Church) insisted that except the Gentiles who turned to Christianity were circumcised they could not be saved (Anderson $[58,88]$ ). The Jerusalem Council of AD 49 discussing this controversy decreed that circumcision should not be imposed upon the Gentiles because salvation is by grace (Acts 15: 1-29[59]).

Paul in radical shift gives circumcision a new and significant understanding; Obedience to the law gives circumcision its true value. Paul talks of an inward circumcision, the circumcision of the heart, which is of benefit only when one truly observes the Law. Marshall et al $[25,12]$ says that Paul's argument against necessity of circumcision was that the circumcision made without hands also referred to as the circumcision of the heart is what mattered most (Col 2:11[15]; Rom 2:28-29[27]). This circumcision of the heart, he says is effected by the gift of the 
Spirit and it has rendered circumcision unnecessary (Phi. 3:3[60]; Gal. 3:3; 5:3-5[26]); Rom 2:28-29[27]). It is this gift of the Spirit that defined the Christian. The New Testaments conclusion that relationship with Christ sealed by baptism outweighs all other mediums of connecting with God raises the question of the continued stress and relevance of circumcision in the NC. If the cross is the way into the covenant and circumcision is no longer required, this study is justified in asking why the practice is central to the NC.

\subsection{Origins and Development in Baptism}

Baptism according to McGrath [49,528] is the second major sacrament in Christianity. Baptism may be understood as the rite of washing with water as a sign of religious purification and consecration (Placher [61,183]. The crucifixion of Christ is the most important element of the new covenant. Entering the new covenant means being baptized into Christ's death and being raised with him into new life (Rom. 6:11 cf Col. 2:12 [20]). Christian baptism is the sacrament of initiation into life in Christ. It marks the beginning of the journey of faith and discipleship that lasts throughout one's life. Authorization of baptism is often found in the command of Jesus in (Matt.28:19-20 [19]).

In the act of baptism Jesus enters into solidarity with the lost humanity. Baptism is a sure sign of fellowship and union with Christ and all the saints. Migliore [33, 283] says that baptism marks the beginning of the Christians participation in the life, death, and resurrection of Christ. This truth is clearly symbolized when the candidate goes down into the water (a picture of going down the grave) and coming up out of the water (a picture of being raised with Christ) and beginning a new walk in Christ (Grudem [62,968]).

The practice of baptism in the NC seems to be based on the gains made as from the times of the early Church. However its departure from the early church is based on the choice of two specific times for male and female infant baptism. On the eighth day male infants on top of baptism are circumcised; female infants are baptized on the fourteenth day. The question remains why and when this departure was chosen as the path to God.

\section{Research Design}

This study employed the exploratory research design. Exploratory design serves the purpose of drawing together diverse information into a unified interpretation, thus evoking ideas and insights ([Kothari 63,36; Peter 64,56]). The purpose involves looking at the events and activities that precipitated the double rite of passage in the $\mathrm{NC}$ and their significance at that time and how they help to explain the rites in the NC today.

\subsection{Study Area}

The study was undertaken in Rarieda District (Total Area: $798 \mathrm{Km}^{2}$-Land: $403.4 \mathrm{Km}^{2}$; Water 394.6: $\mathrm{Km}^{2}$ ). Rarieda
District is one of the new districts in Siaya County of Kenya. Rarieda District was curved out of Bondo District in 2007. Rarieda District lies between $0^{0} 26^{\prime}$ to $0^{\circ} 90^{\prime}$ and longitude $34^{\circ} 10^{\prime} \mathrm{E}$ and $34^{0} 35^{\prime}$ E.-(Population and Housing Census, 2009). Rarieda was chosen for this study because it is the home of origin of the late prophet Johana Owalo the founder of NC, the foundation of the first ever congregation of NC. It is also the headquarters of NC in Kenya and home of the immediate former Archbishop the late Gideon Charles Owalo.

Administratively Rarieda district has two divisions namely Rarieda Division $\left(178.4 \mathrm{~km}^{2}\right)$ and Madiany Division $\left(221.2 \mathrm{Km}^{2}\right)$. Politically Rarieda District also covers Rarieda Constituency.

Table 1. The size and distribution of administrative units is as below:

\begin{tabular}{|c|c|c|c|}
\hline Division & Area $\left(\mathrm{Km}^{2}\right)$ & $\begin{array}{c}\text { No. of } \\
\text { Locations }\end{array}$ & $\begin{array}{c}\text { No. of } \\
\text { Sub-Locations }\end{array}$ \\
\hline Madiany & 221.2 & 4 & 13 \\
\hline Rarieda & 178.4 & 4 & 10 \\
\hline Total land surface & 399.6 & 8 & 23 \\
\hline
\end{tabular}

Source: Rarieda District Development Plan 2008-2012[65]

The population figures from the national census of 2009 indicate that the District has a total population of 134558:Males 64473; Females 70085- (2009, Population and Housing Census).

The district has an average population density of 334 persons per square kilometer. Rarieda Division has a higher population density of 368 persons per square kilometer.

Table 2. Rarieda District Population Distribution and Density

\begin{tabular}{|c|c|c|c|c|c|}
\hline DIVISION & Area $\left(\mathrm{Km}^{2}\right)$ & Males & Females & Total & Density \\
\hline Madiany & 221.2 & 33184 & 35416 & 68600 & 306 \\
\hline Rarieda & 178.4 & 31289 & 34669 & 65958 & 368 \\
\hline Total & 399.6 & 64473 & 70085 & 134558 & 334 \\
\hline
\end{tabular}

Source: 2009, Kenya Population and Housing Census[66]

\section{Research Findings and Conclusions}

\subsection{Prophet Owalo: The Founder of NC}

The ministry of Johana Owalo like that of Jesus Christ and that of Mohammed was for a short time; however its impact has long survived him. Johana Owalo was born in the K'ochieng clan of Asembo location within the Luo community. Johana Owalo is believed to have been born in 1871(Ogot [45,690]; Opwapo [67: 58]). Johana Owalo's father Abor had two wives. The birth of Owalo the last born of the second wife is surrounded by several legends. One such legend explained by Rev. Andrew Nyanya states:

On the day of his birth it is said that one of the bulls belonging to his father's herd while on the grazing field and as it was sharpening its horns on an anthill it encountered a snake that twined itself on the bull horns and remained there. 
Nobody attempted to remove the snake. Puzzled by this amazing spectacle Owalo's father took some grains in an ondong (small basket) and went to consult a medicine man close by. The medicine man assured him that the incident was a harbinger of the imminent birth to take place in his home of a child with special qualities. Later in the day after the herd returned home Owalo was born and at that very moment the snake disentangled itself from the bull's horns and left the compound without harming anybody or being harmed by the members of the homestead [68](See Opwapo 1981:57).

While it is not possible to account for this early period of his life, it can be deduced that like all Luo boys of his time he grew up performing the routine manly duties expected of boys and men in the Luo society. Owalo got married to two wives Elizabeth Alila and Madara daughter of Ajulu (Owalo $[69,24])$. Elizabeth is the mother to the late Archbishop Gideon Charles Owalo the immediate former head and spiritual leader of the Church.

Information on prophet Owalo's education and work is rather divergent. Owalo's experience of and education in the European education system and the missionary religion takes a two pronged picture. Bishop Eng. Caleb Olali [70:22] argued that Owalo was among the first students sent to Maseno at the request of Willis the missionary who had just started Maseno School. Chief Adhola of Asembo sent his son Odindo, Adem and Owalo. The other picture is that given by Archbishop Owalo [69,25] who concurs with Opwapo $[67,63]$ that Owalo was a student at the Roman Catholic center at Kibuye in 1905. Owalo later moved to the Roman Catholic Mission at Ojola where for four months he received formal education. It is here at Ojola that he got baptized. Burgman [71, 34\&288] suggests that he was not only an early convert to Christianity but actually the first Luo to be baptized at Ojola on June $13^{\text {th }} 1906$ getting the new name of Joanno Robert. Judge Robert Noble was his God-Father.

Prophet Owalo must have had contacts with both Muslims and Europeans during the closing years of the $19^{\text {th }}$ century or the initial years of the $20^{\text {th }}$ century. There is evidence that a group of porters carrying supplies for the railway construction works moved from Asembo led by Adhola who later was to be the chief of Asembo (Ndeda[36,4]; Opwapo[67]). Given these circumstances Owalo must have been a frequent visitor to the town of Kisumu. He also interacted with fellow Africans who had appropriated and imbibed the European education; a good example being Daudi Kwata who trained at Kaimosi and who later played a significant role as the match maker connecting him with his wife Elizabeth Alila (Opwapo [67], Owalo [69,26]).

In the same year of his baptism Owalo moved to Mombasa and stayed for one year working for Judge Alexander Morrison as a "boy" house help. Judge Morrison had been a judge at the Kisumu Law Courts between 1904 and 1906 and had now been transferred to Mombasa. It was here in Mombasa that three events that seem so much unrelated are to occur and be experienced by Owalo and eventually change the course of his life. The first event is in his experience with

the Muslims. The second is a series of heavenly visitations by Prophet Owalo guided by angel Jibraeli and Rafaeli. The third, though not clear is the impact Judge Morrison Unitarian faith had on Prophet Owalo's later religious life.

Given the predominant presence of Muslims in Mombasa, Owalo was attracted to Islam. According to Archbishop Owalo's this occurred after receiving God's calling in 1907: "After receiving this message Owalo left Catholic and joined Islam where he was baptized "Omari" (Owalo $[69,26]$ ). Another significant development in the Prophets life is his submission for circumcision. Ndeda [36, 5] suggests that he must have been circumcised during the brief period of worship with Muslims in Kisumu. Several aspects of Islamic worship are found in the $\mathrm{NC}$ for example, the male adherent's dress code (that include the kanzu and cap), removal of shoes in worship space and kneeling in prayers facing Kibla among others.

The second event was Owalo's call in 1907.This experience ushered Prophet Owalo into the first second and third heaven. He met the angels and saints but he came face to face with God and therefrom came out with a new lesson that God alone is worthy of worship. Jesus is but a messenger and should not be worshipped. He learnt that the Jews, Arabs and Luos were able to access heaven whereas the Bunyans and Goans were denied entry. Several issues particularly in regard to important Catholic Church doctrines were rejected. The theological identity of the NC is spelled out in the pertinent doctrinal issues raised in the six chapters of the $\mathrm{NC}$ scriptures.

When J.J. Willis suggests that Owalo 'is practically a Unitarian' he must be referring to Owalo's departure from the Trinitarian faith and belief of both the Roman Catholic Missions and the Protestant Missions prevalent. The source of this radical departure may be connected on the one hand to the faith of Owalo's employer and on the other to Owalo's visions of the heavenly excursion. Ogot [72] notes that "Morrison who was a Unitarian was the son of an Anglican pastor in England" (Ogot [72,256]; Ogot [45, 690]).The Rev. Willis, and Ogot all concur that the Unitarian Judge Alexander Morrison impacted on Owalo (Ndeda [36,7]).

In these visions Owalo came to realize that there is only one God who requires all creatures to worship him, Jesus included. On this note the Trinitarian formula of God the Father and God the Son and God the Holy Spirit collapses (Ogot [45]). Jesus stressed to Owalo that they were equal before God as messengers. After this visitation, it is said that Judge Morrison noted an odd behavior in Owalo who could sometimes speak to unseen persons. Owalo took time to explain his experiences and more particularly his commissioning to preach to the Luo people.

The mission to the Luo is significant and is repeated in the NC Hymns a good example is:

Nyasaye Noluongo Luo

Oluongo Luo ni Luo duto malamo

En

Biuruka wagone chongwa

kawang'wa omenyo yor kibila
God called the Luo people He called Luos, that all Luos who worship Him Come Let us kneel before Him As we face Kiblah 
(Kitap Lamo, Wende Sabato kod Wende Mony Mag Nomiya Church [73]

In this hymn, God's self-disclosure is manifested in his greatness and his invitation to the Luo people to him; he gives them the Ten Commandments and calls for their obedient response in worship as they face Kiblah (Qibla according to Kateregga and Shenks [74:43] is the direction of prayer that was later moved from Jerusalem to Makkah).

Morrison felt that for Owalo to be effective he needed a sound education background and he therefore advised that he goes back to Ojola for further education (Ogot [45, 691]). He returned to Ojola in Kisumu by 1907 . Here again, he was constantly visited by the angel Jibraeli who challenged his seriousness in undertaking the commission by God. While here at Ojola in 1907, Prophet Owalo eventually broke ranks with the Roman Catholic mission. Owalo declared to the catholic priest that he did not agree with Catholic beliefs on the existence of purgatory, the Trinity, the sacrifice of the holy mass, the intercession of the saints, the pope as infallible head and the bread and wine as the actual body of and blood of Christ (Gale [75]). Owalo did not relent on his stand and he was eventually sent away (Opwapo [67, 69]; Burgman [71,288]; Gale [75]; Ogot [45, 692]).

He left Ojola in the New Year 1908 owing to the outbreak of bubonic plague. Ogot [45] suggests that in 1908 he actually joined Morrison in Nairobi where he was then working as the Town Magistrate. In Nairobi he again moved to the newly established CMS School where he worked as a teacher under Canon George Burns (Ogot [45,691]; Judicial 1/297[76]; KNA1/474[77]). The following year he moved to Church of Scotland Mission CSM at Kikuyu where Morrison had introduced him to Dr. Scott. Here he served both as a teacher and a student. Ogot says that Industrial training was offered at Kikuyu and it was while here that Owalo learned carpentry and typewriting which he was later to teach at CMS Maseno (Ogot [45, 692]).

As a teacher at Kikuyu he had the privilege of teaching Kenyatta who was later to become the president of Kenya. Kenyatta was indeed a student here during this period as can be confirmed by Macpherson 1970[78]; Odinga [44] and Ogot [45]. Owalo was introduced to Kikuyu through a letter from Judge Morrison which said in part: "Here is John whose other name is Omari." The fact that Morrison refers to Owalo by his Muslim name is an indication of how close they were. His letter of recommendation demonstrates the level of trust he had upon the character and the person of Johana Owalo.

It is likely that Owalo and J.J. Willis met during the Nairobi conferences. From the communication between the Rev. Willis and Scott it is apparent that Rev. Willis is already aware that Owalo's preaching and teaching go contrary to the teachings of the European missions. Despite this Willis saw the potential inherent in Owalo for the development of the church in Nyanza and in October 1910 Owalo moved to Maseno School as a member of staff. As a member of the teaching staff he taught his students Reading, Writing and Kiswahili. While in Maseno the Missionaries observed that
Owalo at one point in time changed and even refused to worship together with the members of the community (Ogot [45,692]).

He left Maseno CMS in 1912 to formally launch the Nomiya Luo Mission (NLM). Owalo disagreed with the missionary teachings on the Trinity, worship of Mary, Clerical marriage, Monogamy among other issues. Archbishop Owalo concludes that "He found the missionary teaching fallacious and with no biblical basis. Owalo was summoned to appear before the first Maseno Council to explain his stand. Maseno was disturbed by Owalo's defiant stance and more by his teachings that embraced polygamy while rejecting the doctrine of Trinity and the divinity of Jesus Christ. The time Owalo spent at Maseno and Ojola are clearly marked and remembered by the adherents in song. In the hymn Janabi Luongowa e Got Malo (The Prophet is inviting us to the Mountain)[73] we see the prophet inviting the adherents to Ojola where he has received the word of God through a revelation.

Prophet Owalo moved back to his home area where as from 1912 he gathered around him a group of followers. The movement according to Opwapo was not registered until 1914 when the Provincial Commissioner then Mr. John Ainsworth demanded from Owalo the name of this new group (cf Bishop Eng. Olali [70,36]). Owalo asked for one day of prayer and he came back the following day with the name of Nomiya Luo Mission which literally means the Luo Mission that was given to me( Opwapo:67). Because of the trust that Ainsworth bestowed upon him, Owalo was allowed to act as a sub-headman for the Kochieng clan (Opwapo $[67,102])$.

At his home area at Orengo Owalo erected his first church amidst a deep cultural controversy. According to Bishop Agedi [79] Owalo happened to have been married before his elder brothers and this was a source of serious customary conflict. The Luo custom decreed that Owalo for the reason of his marriage could not eat with his brothers and neither could his wife prepare food for them or her parents in law. Owalo were forced to look for alternative accommodation at Midai's home; a polygamous man who had seven wives. Owalo and his wife were accommodated in Luke Siwalo's hut (Bishop Agedi [79])

It is here because of conflict of culture that Owalo's movement suffered its primary setback. Owalo's first setback was much more than an internal rivalry but a fully-fledged war based on the clash of two cultures: the Luo cultural beliefs and the mission based beliefs. Owalo $[69,28]$ ) argues that Midai's first wife Ramba Akumu Nyowesi practiced divination and for this reason, fearing that Owalo's religion would turn away her would be clients plotted to get rid of it. Together with her son Ondiala and Tado (Owalo's elder cousin) they declared Owalo's presence unwelcome (Owalo [69,28]). To demonstrate his displeasure with the Owalo's faith, Tado, razed down Owalo's first Nomiya Luo Mission church at Orengo. The tension was heavy and Owalo was forced to move on.

A second church built in Katwenga of Uyoma location 
suffered the same fate as the one at Orengo, in 1915. According to Opwapo [67], One, Henry Alemba got converted to the NC during a visit he made to Asembo and when he got back to Uyoma he embarked on evangelization of Uyoma. For this effort Alemba was beaten up. When Owalo learnt of this misfortune he decided to visit Uyoma in person. Owalo's former colleagues at Maseno, decided to report Owalo to the chief and since the chief failed to deal with the matter to their satisfaction they went to the District Commissioner (D.C.). Owalo was then invited to Maseno to appear before the DC. Owalo won the case and thereafter the two year probation slapped on him by the Provincial Administration was lifted and his movement consequently registered.

Prophet Owalo, having received this hostile reception, decided to move to Gem in order to start on a clean slate with his friend Kwata. On his way he had a stop at Oboch where the elders' of the K'ochieng clan persuaded him against settling in Gem, the home of his in-laws. Consequently, several elders donated pieces of their land to Owalo. It is here that Oboch headquarter was founded. Prophet Owalo was energetic and zealous for the cause for which he was commissioned as apostle to the Luos. His ministry had no boundaries he sought all and in their daily chores and endeavors. Immediately thereafter, he sends the same disciples to evangelize other regions. Their basic message was that: "No one else to be worshipped but God the Father and that worship is to be on the Sabbath." Owalo [69]

Prophet Owalo's extensive evangelism began as it were in Jerusalem, then to Judea, Samaria and to the rest of the world (Acts 1:8 [80]). His Jerusalem was his immediate family members and the K'ochieng clan. He soon won over his own brothers Nyunja, Obado, Okech Ojode. By 1915 his message had reached Kandaria in Omia. Thus, most of the Asembo clans had been reached in the first wave of evangelism. In ever expanding concentric circles the evangelism efforts of Owalo and his determined followers went out to Yimbo and Gem, to Kisumu Manyatta and Nyakach and even further south to South Nyanza and Tanzania. Johanna Owalo opened catechism classes in order to prepare candidates for baptism. In 1913 he had come up with an NC catechism that he married so well with the Anglican catechism (Opwapo [67:93]).

Johana Owalo's effort to disseminate that which he had acquired in his long experience as a student and as a teacher stands out in the NC effort to launch secular education. The first independent schools in Nyanza and by extension Kenya were opened by the NC (Owalo [69,30]; Bishop Eng. Olali $[70,48])$.These schools were opened in the newly planted churches. Johana Owalo himself led by example being a teacher at Oboch. According to Opwapo [67,93] Owalo taught Arithmetic, Reading, Writing and Religion. The classes were generally held in the afternoon and pupils were taught up to standard two. His desire to establish strong institutions was however thwarted by the government's consistent efforts to deny these schools recognition and registration.
The end of an illustrious career came suddenly and sadly. Owalo, who had visited the adherents in Nyakach around the time of the Christmas festivities1919, came back feeling unwell (Bishop Eng. Olali [70,39]; Opwapo [67,103]). It is highly probable that he contracted small pox that was prevalent in the region at that time He died on Jan 111920 at Oboch surrounded by his disciple According to Eng. Caleb[70] he asked the disciples to go into the church for prayers. He also instructed them to sing two of the church hymns: Nyasaye ne oluongo Luo (God called the Luo People) and Nyasaye nene Ochiko ni en achiel (God directed that he is one). He passed on as the disciples were praying at 3.00 am.

The fact that Owalo did not leave a leader designate for the church was a source of lengthy and painful wrangles that had to be adjudicated by the provincial administration on several occasions. However the determined and concerted efforts by the disciples ensured that newer and distal areas were evangelized. Churches and schools were planted albeit the challenges in administration of the church that witnessed one wrangle after another. Although wrangles and splintering still plague the $\mathrm{NC}$ to date the outstanding feature in the $\mathrm{NC}$ and sister churches is the upholding of the original tenets of the church as were received from Prophet Johana Owalo.

\subsection{The Double rite of Passage: Historical Background}

Islam and Christianity had profound and significant impact on the cultures that they came in touch with. Both impacted the Luo culture in such significant proportion that a new culture was created in all areas where the adherents practice the same. Prophet Owalo is said to have gone to a lot of trouble in order to procure his own circumcision from the Muslim adherents. For him later on to advocate the same together with baptism as a pillar and a sign of membership into the $\mathrm{NC}$ is a significant milestone that demonstrates the influence of one religion over another. Eventually a unique practice has been born so different from Christianity and Islam from which it arose; the hybrid product is the current practice in the NC.

That the NC has borrowed and internalized several important features from both backgrounds giving them a new value and outlook can be best explained taking C.S. Song's correlation between Gospel and culture. Song therefore suggests that whenever the Gospel is introduced and established in a new culture it is "transposed" like a sweet melody into a new key; the Gospel when transposed from its biblical world to other cultural worlds undergoes change itself as well as causing these other world cultures to change (Mugambi $[4,1]$ ). This dramatic change is evidenced in the fact that the Luo people who hitherto did not practice circumcision have now taken in not only circumcision and the practice of seclusion of women after birth but also the practice of baptism. A gospel that only advocated baptism has now been transposed to also proclaim circumcision and the blood purification of women after birth. A culture that practiced seclusion of women after birth of three and four 
days now observes forty and eighty days of seclusion.

The double rite of passage of circumcision and baptism in the NC is unique. Circumcision in the NC seems to have its roots in Judaism but here it is done in the context of baptism. Most Christian denominations consider circumcision as obsolete having been replaced by baptism. Therefore to have both the rite of circumcision and baptism gives the NC practice its unique quality. The historical as well as socio-cultural aspects of the $\mathrm{NC}$ is well fleshed out in the interaction and clash of four cultures, the Luo culture, the European mission culture and the Colonialist culture and the Islamic culture. The Luo culture particularly on the socialization process and Luo Religion provided the solid foundation and springboard which propelled prophet Owalo into a dialogue with the other cultures.

The historical significance of the heavenly visions and their continued significance to the NC today is well defined in the theology of the $\mathrm{NC}$ as presented in the faith and practice of the adherents. The Luo culture and religion did not require the adherents to undergo circumcision as the initiation rite. Baptism and circumcision the foundational rites of admission into the $\mathrm{NC}$ are alien to the Luo culture.

\subsubsection{The Luo Culture}

Paradoxically, the European missionary enterprise was well received among the Luo people and this could be attributed to the shared belief in a supreme being Nyasaye. The Luo believed in the existence of a supreme being Nyasaye who is the source of all livelihoods (Ocholla-Ayayo [81]; Ogutu [41]; Achieng [42]). Nyasaye is recognized as the creator, originator, or source of life and of the entire universe which $\mathrm{He}$ continues to sustain. Consequently Ocholla-Ayayo [81] argues that the Luo culture holds that the entire universe is God's creation and that human persons were given the responsibility of taking care of all resources from God. The Luo are also the custodians of a distinct set of values, beliefs and norms which are believed to be gifts from God to the community.

The relationship between Nyasaye and man is mutual and asymmetric. Man must give Nyasaye his due respects, honor praise, and keep his constant sacrifices, follow the rules and law of the society. Nyasaye in turn gives man good health, wealth prosperity and extends his mercy upon man, gives his blessing and establishes his good judgment and peace among men (Ocholla-Ayayo [81], Achieng [42]). This understanding of God's sovereignty and the stipulations for human beings that emanate from him as he relates to them makes it possible to appreciate the covenant relationship in circumcision and baptism.

\subsubsection{Missionary Activities in Kavirondo and the NC}

The first missionary activities to Nyanza were an extension of the mission enterprise in Buganda which started after a passionate appeal by H.M. Stanley in the Daily Telegraph1875.(Nthamburi [38,84];Opwapo [67, 49]).This appeal did yield a speedy response and the first CMS Missionaries reached Mutesa's court on $30^{\text {th }}$ June 1877. This group was immediately followed by the Catholic White fathers. Both these teams used the Zanzibar route that was pioneered by Swahili traders.

In September 1892 when Bishop Tucker, the third Bishop of the Diocese of Eastern Equatorial Africa made an important tour that took him to the headquarters of Chief Mumia's kingdom he was touched by the sight of the un evangelized village and said: Can nothing be done for Kavirondo? If only Christians at home could see us surrounded by swarms of these poor ignorant people, and unable even to promise them teachers, they would surely have pity on us and them (Elizabeth [82])

In July 1904 the urgency for a mission presence in the area to the East that was referred to as "the Kavirondo District." was amplified in a paper read by the Rev. Willis to a conference (Uganda Notes R 201 G3 A7 04[83]). Willis notes in his paper: "The completing of the railway has revolutionized the condition of things on the other side of the Lake even more than it has here. The sleep of centuries has been suddenly broken by the rude inrush of civilization." Immediately Archdeacon Walker accompanied Mr. Willis to assess the situation. The result of the visit was the opening two stations in Kavirondo: One among the Bantu-speaking Kavirondo, and the other among the Nilotic -speaking Kavirondo.

The founding of the CMS center at Maseno in 1906 by the Reverend J.J. Wills had such a great impact and success. According to Ogot the CMS church in Nyanza was lucky to have Rev. J.J. Willis a man of remarkable personality and a firm believer in Venn's policy and one who "was strongly opposed to the paternalistic attitude of most of the Europeans missionaries working in Kenya." The "three self-policy", aimed at making the church in Africa an indigenous institution by setting up as quickly as possible a self-supporting, self-governing and self-propagating church (Ogot $[45,684])$.

Right from the beginning Willis took upon himself to influence the chiefs to bring their own sons to acquire the secular education as well as religious instructions. In 1906 four small boys- Onduso, Odindo, Owiti and Orao all sons of Luo chiefs were transferred from the Friends Mission Kaimosi to start Maseno School (Ogot [45,688]; Elizabeth $[82,15])$. Eventually The Rev. J.J. Willis succeeded in establishing a church which Africans could truly regard as theirs (Ogot [45,686]). Barrett [84,15] concurs saying despite the settler mentality in the Anglican diocese emanating from the White Highlands, in Nyanza the CMS managed to build up a strong indigenous church. A favorable external environment was provided by the Provincial administration led by John Ainsworth which supported the work of the European Missionaries (Maxon, [85.208]).

Owalo Joined CMS Maseno as a member of staff Owalo in 1910, after a lengthy stay at CSM Kikuyu. With time Owalo and the establishment were in disagreement. According to Archbishop Owalo the disagreement was due to the fact that the missionary teachings were fallacious having no biblical basis. Ogot [45] notes that The Rev. Willis observed 
Owalo's moods changed and he even refused to worship together with the members of the community. The Rev. Willis called a council meeting to try and resolve the differences but seemingly they were irreconcilable. Owalo left Maseno CMS in 1912 to formally launch the Nomiya Luo Mission (NLM) and continue his teachings that rejected the doctrine of Trinity and the divinity of Jesus Christ while embracing polygamy. This is the second time Owalo leaves a mission station with the label of a 'rebel.' John Ainsworth support will enable the new movement to be registered in 1914. Behind all these is the intrinsic influence of the heavenly visions and excursions.

\subsection{The Socio-cultural Basis: Discourse of the Heavenly Visions and Excursions}

Theology according to Mugambi [86:7] may be understood as a systematic discourse about God that concerns itself with the origins, purpose and destiny of being. The theology and the worship practice of the NC are grounded in the six chapters of the NC scriptures. These Scriptures are said to have been written in a Kiswahili version that was called: Upanga Mkali.

In the first chapter identified as Nomiya Sula achiel,(Owalo[87,93]) Jesus' identity as an apostle rather than as the son of God is underscored. Consequently God the Father will be progressively identified as the only worthy of praise, honor and homage. In the third heaven Owalo recognizes Jesus and immediately moves forward to worship Him but Jesus denies him that opportunity and instead leads him to God before whom they both kneel and worship. Jesus was an apostle and for this reason he expects an apostle like him not to bow down to him.

This revelation takes place as from March 1, 1907. This date stands out as a special date in the NC (Owalo [87,93]). It is the date that God revealed his purposes for his people through Johana Owalo. According to Archbishop Owalo $[69,48]$

The main aim and objective of Nomiya Church as a Christian church is to preach and teach the people; new converts and followers to know, believe and follow that on the first day of March the year, one thousand nine hundred and seven, 1907 God manifested Himself to prophet John Owalo. On this day God selected him as an apostle. (Owalo, $[69,48]$ )

The NC Scriptures are so packed with the theological insights that in essence define and describe the theological pillars that hold the NC together. Johana Owalo in a special revelation finds himself transported aloft by angel Jibraeli to the first, second and third heavens (Owalo, [87, 93]). We do not know how many times Owalo had this special opportunity to experience what would later differentiate the $\mathrm{NC}$ from other faith groups but according to Archbishop Owalo the prophet himself talked of about twelve times.

According to Owalo, $[87,93]$ in the first heaven Johana Owalo fails to recognize the Pope among the saints but he is able to recognize Mary, Peter and other people. The angel
Jibraeli then explains that heaven is for those whose names are written in the book of life and those who also pay visits to heaven. Johana observes that the first heaven has a big congregation of saints. The second heaven he identified as the abode of angels (Owalo [87,94]).

In the second chapter Nomiya Sula Ariyo (2) Owalo, [87,94], God the Father is revealed as the center of worship and adoration. He stands separate and distinct from his creatures who must direct their homage directly to him and not to any other or through any other. In this chapter God expresses his displeasure at the behavior of creation that has rejected worshipping him and is now worshipping creation. Identifying Owalo as his messenger God directs him on mission saying: "But as for you I am sending you to carry aloft the sharp sword, whoever believes, is accepted but he who refuses let him be."

The second aspect of this vision comes out in what would be referred to as 'Owalo's ladder.' People in the world 'olumwengo' recognize way above them a bunch of very ripe fruits and each group raises ladders to reach the fruits. Christians even after placing their ladders on top tables could not reach the fruits. Then angel Jibraeli gave Johana a ladder telling him: "Throw away all the other ladders so that they break into pieces, whoever refuses to use this one let him be." Consequently, Owalo was able to reach the ripe fruits. God is clearly telling Owalo not to rely on any other means to reach him. This part of the revelation augments the earlier lament by God that men have discarded the right worship and have taken to worshipping creatures. It is a clear demonstration that God is providing the right way to Owalo.

Progressively these heavenly visions reveal that God is the source of all good and human beings can appropriate these goodies only as they rely on the means and ways that are made available by God himself; for example Owalo's ladder as demonstrated above. The visions also reveal that God chooses those people who are to act as instruments and vessels to disseminate abroad his eternal purposes for his people. God's free will is expressed in the opportunity that God offers to all. Each and every person is given the choice to use Owalo's ladder or seek another alternative.

In chapter three Nomiya Sula adek Owalo, [87,94]the primary purpose and reason for God's calling of Johana Owalo is reiterated. The call goes back to that day in Mombasa on the first day of March 1907 when Johana Owalo is challenged by the angel Jibraeli: "If you accept to carry the message that God is about to give you then you will forever be considered as a servant of God." The message delivered to Owalo suggests that he has been identified as a messenger or a prophet to carry a message to an un specified destination or person. The acceptance of the commissioning and the content of God's message are tied to the eternal recognition of Owalo as God's perpetual messenger. Prophet Owalo has an opportunity to accept this high calling or disregard it altogether. Progressively Owalo is confirmed as the prophet while at the same time the content, the potent and the import of the message are made known to him.

Prophet Owalo is repeatedly challenged in his mission. At 
Ojola the angel Jibraeli appears again to the prophet Owalo questioning and challenging his involvement with the ministry he had previously been called to: "You were sent to proclaim the word of God yet you are currently teaching human words...Forget those are blind men's words; but you teach to the people the word of God... Separate yourself from them and teach the word of God only." [Owalo 87,94-5]

The angel Jibraeli wants Owalo's ministry to project Jesus as the messenger of God only and not as one to be worshipped. Teaching and projecting Jesus as the son of God who deserves due homage is accordingly a blind teaching that should not be entertained. Mary is also to be seen in the light of the one who received a direct communication of what God was to do through her but the said words are not to be used to elevate her to a position of reverence. The emphasis here seems to be that although Jesus and Mary were instruments in God's plans for salvation of humankind none of them were to be regarded as objects of worship [Owalo $87,95]$. This tally with the position above that Jesus was a messenger like Owalo.

Coming to Owalo at Ojola the new center of the Roman Catholics could be construed as a direct attack on the teachings and practices carried out at this center in worship. The fact that Owalo is regarded highly as the first convert from Luo land and consequently as an interpreter by his superior Father Grimshaw is an indication that the angel is attacking his current occupation. For what he is teaching as a catechist seemingly is what the angel is attacking and referring to variously as "human words" which are "blind men's words." This then is suggestive that what is being taught has deviated from the master teaching. Mary was never to be an object of worship or a channel through which prayers were to be reflected to God.

In the fourth chapter Nomiya Sula angwen Owalo, [87,95] the emphasis is God alone is worthy of worship. In the third heaven Johana Owalo, Jesus and angels Jibraeli and Rafaeli presented themselves before God and bowed down before God in worship. However Johana Owalo on various occasions bows in worship to Jesus who tells him not to do that. The angel Jibrael warns Johana vehemently saying: "Is there an apostle who worships another apostle or is there an angel who worships another angel? Whether you are on earth or wherever you are it is God alone to be worshipped." It is clear and repeated for clarity and for emphases that God and God alone is to be worshipped and none other, wherever one is.

In a very brief but compact sentence the Spirit is recognized as being part of the third heaven but even here it is associated with God the Father and not Jesus: "Prophet Johana Owalo on several occasions noticed the Holy Spirit emanating like smoke from God the Father and not from Jesus." This view agrees with the earlier view in the Nicene Creed that had referred to the Holy Spirit as "proceeding from the Father." This view contradicts the conclusion of the Western churches that reworked the Niceno-Constantinopolitan Creed and referred to the Holy
Spirit "as proceeding from the Father and the Son" (McGrath [49,340]). According to McGrath [49] this "double-procession of the Holy Spirit" has remained a source of intense irritation to Greek writers.

The quality of worship expected is identified as that from a contrite heart: "There is no sacrifice other than that offered by a believer who truly worships God with the whole of his heart." (Owalo [87,95])Worship then is a condition of the worshippers attitude that signify his self-giving and surrender of one's will to that of God. Owalo has this direct connection as seen in the following quote: "On several occasions God gave apostle Owalo a long rope. The apostle held one end of the long rope here on earth while Jesus held the other end in heaven." (Owalo [87,95])

The Roman Catholic Church understanding that there are other medium through which adherents prayers could reach God is hereby denied through this direct connection to God. The NC way is the only way and this is affirmed in the clause that is added to the creed recited in the Nomiya Church: (Kendo ayie)...kendo kuom Nomiya mabiro miya ngima which translates as: "(And I also believe) on Nomiya through which I will receive eternal life." [87,22] Being a member of the NC and being bound by all that Prophet Johana received from God opens the way to eternal life.

In Chapter five Nomiya Sula Abich Owalo [87,95-96], Prophet Owalo gets the express affirmation that he needs to preach the pure Gospel whether 'in season or out of season.' Johana Owalo is to preach the pure word of God because Jesus himself had proclaimed the message without fear or fervor as it is recorded in the Gospel of Matthew chapter 18.One would surely ask: what is this special message in Matthew 18 that demands heavenly notice. Matthew 18 is Jesus' answer to the disciple's question of who is the greatest in the kingdom of heaven. The key teachings here are about the duties and roles of a Christian and a Christian community: that the greatest should humble himself like a child, should have a special place for the children, seek and reconcile with his brother in fellowship and be ready to forgive the brother from his heart of any wrong doing.

Matt 18:1-6 teaches on humility where it says that the badge of entry into the kingdom of God demands that one becomes like a child. He who welcomes a child in the name of Jesus actually welcomes Jesus himself. Anyone who puts a stumbling block before one of the young believers should have a millstone tied around his neck and drowned in the depth of the sea. Those whose actions cause the little believers to stumble will themselves suffer heavy consequences. Jesus also cautions that the little ones should not be despised because in heaven their angels continually see the face of God the Father. Speaking on offences by self to self, Jesus cautions believers not to put stumbling blocks before others. Jesus also asks them to introspect themselves and uproot anything that causes them to stumble. In the same vein Jesus puts great emphasis on forgiveness as a key pillar of the church.

On those offences where others hurt us, Jesus says they need to be reproved. If a member of the church recognizes 
the fault of another he should seek him out. However, if they fail to agree then one or two other members of the church should be invited to listen and if they too fail to resolve the matter then the whole church should be involved. The church is empowered to bind or loose for whatever is bound on earth will be bound in heaven. God is ready to take cognizance of and also confirm the sentences that the churches pass. Jesus shows the willingness of God to answer prayers. The church is not only assured of God's presence in its midst but of the efficacy of her joint prayers.

On Forgiveness Jesus seems to suggest that forgiving has no ceiling it should not be a mere seven times but seventy-seven times. God keeps account we need not count the number of times we forgive. This is the pure message that Owalo should proclaim. This passage brings out the essence of the Church as a community of believers united in one baptism, whose hallmark is humility and forgiveness and whose co-duty is to seek and reconcile God's people to God.

Verse 2 defines the destiny of men. Johana Owalo recognizes that heaven is such a beautiful place where the world communities would like to enter. The angels have blocked the gate. The Jews entered followed by the Arabs. But when the Europeans attempted entry the gates were shut on them and the angels pushed them out literally kicking them. Banyans and Goans and other ethnic groups were also pushed out.

he reason why the Pope had no access to heaven as earlier noted in chapter 1 is hereby elucidated in chapter six Nomiya Sula 6(Owalo [87,96]: "Because the Pope has blocked the path of Christ God in turn has blocked his path." The Pope has blocked the path of Christ through his gods and Mass. This chapter reiterates what was mentioned earlier that the pope is not recognized in heaven because he does not visit heaven and those who do not make such visits are not known. When Owalo in the twentieth century talks of the pope being denied access to heaven because corruption in the church one is reminded of the factors that led to the call for Reformation in the sixteenth century. The Reformation agenda of the sixteenth century presented a platform on which the ills that bedeviled the church in the Medieval years were discussed. The corruption in the church had reached such high proportions that the church lacked that moral authority as the salt and light of the world. Such a corrupt institution together with its leadership may not be the channel and instrument of God's grace to his people; and this could be the reason the pope is said to be blocking the path to Christ.

In verse 4 mass is declared as un acceptable sacrifice but a contrite heart that covers all that God desires of his people with prayer. The only acceptable sacrifice is prayer that leads to the desires of God. In the third heaven God actually removed the bread that Johana Owalo had partaken while a believer in the Roman Catholic Church. This was sin. Verse five also identifies that there are two paths leading to heaven, a narrow path and a wider path. The narrow and hard path leads to God while the wide and easy road leads to the devil. On your way to heaven from the earth the narrow road is to the left while the wide road is to the right. Purgatory is not in the kingdom of God but only Heaven and Hell. Every NC believer lives in great anticipation of a better world at the end of life here on earth. This expectation is captured in the many facets of the NC worship; in her prayers and Hymns. One such solemn hymn Adwaro mana in Ruodha, I need you only my Lord, when my days on this earth come to an end, Jehovah come, hold my hand.[73]

\subsection{The Heavenly Excursion and the Mission to the Luo}

It is significant to note that the heavenly excursion revealed to Owalo two things: First, the ills and flaws in the missionary teaching and theology and secondly, that he had a mission to bring the Luo nation into the knowledge and appropriation of God's blessings. Like Paul who had an express mission to the Gentiles (Acts 9:15) [88]. Owalo also had a message specifically for the Luo people. Owalo realized that Jesus was not to be worshipped: "Jesus told him that they were equal as both were messengers of God, and that Johana was to return to preach the gospel of all the Luo people" (Ogot [45]).

According to Ogot [45] this experience forced him to leave the Anglican Church because its teaching on worship is based on the wrong premise worship of "three gods." Among the many outstanding belief systems entrenched in the Catholic worship that Owalo out rightly rejected included ; 'beliefs in the existence of purgatory, the holy trinity, the sac,ifice of the holy-mass, the intercession of the saints, the Pope as the infallible, and the bread and wine as the actual body of and blood of Christ"'(Ogot [45, 691]).

The ills were compounded in Owalo's vision by the fact that the leaders of the main stream churches and particularly the Pope was not recognized in heaven and that the Whites as well as some major ethnic groups were apparently locked out of heaven: "The white races attempted to enter in after them, but the Angels closed the gate on their face and chased the white men away, kicking them... the Indians and Goans were also chased away. (Ogot, [72,262])

Owalo also introduced another angle in the twist by advocating for polygamy. The Rev. Willis perturbed by this anomaly says that Owalo: "fights that people should go back to the polygamous marriage in accordance with the Old Testament" (Owalo [69,26-27]). It is evident that Owalo takes the Old Testaments and its teachings as the primary source of his denominations theology. He does not only go back to polygamy but to widow inheritance and also to rules and regulations pertaining to purification of women after child birth, to circumcision of male members and to many other Old Testament prescriptions on the right relationship of God's people to Him. This is a clear indication of the strong affinity between the Old Testament and NC religious heritage.

The affinity between the circumcision practiced in the NC and that in Judaism is apparent and we can conclusively say that the texts of the Old Testament are the primary texts that have influenced the NC practice of circumcision. Circumcision and baptism have clear roots in the Jewish 
religious practices. Consequently circumcision and baptism on the eighth day for male infants and baptism for females on the fourteenth can be said to be an expression of Christianity in an African manner and a hybrid of Jewish and Christian practices.

\subsection{Prophet Owalo's Religious Experience: Authentic or Not}

A prophet can be said to be the mouthpiece of God. According to Deut.18:18[89] a prophet has two distinct qualities, one that he is raised from among his own people and two that he speaks words given to him by God As the prophet utters God's oracles to the people of God they will either respond obediently or blatantly disobey. The prophet of God does not speak about things that do not come to pass. God provides a clear way of differentiating the false prophet from a true prophet: "If a prophet speaks in the name of the Lord but the thing does not take place or prove true, it is a word that the Lord has not spoken" (Deut. 18:21-22[90]).The word of God is active and has a purpose (Isa. 55:10-11[91]).

The experience of God is a process: "So faith comes from what is heard and what is heard through the word of Christ" (Rom.10:17 [92]). Prophet Owalo's experience of God began in the Luo background of formation. The Luo background seemingly was not a hindrance to acceptance of the Christian teachings as confirmed by Mugambi [86,2]) that the deep religious heritage of the Africans facilitated rather than hindered the acceptance of Christianity. Godin $[93,9]$ Observes that the experience of God is never a first experience. It always has a long pre-history. Therefore, it can be argued that Prophet Owalo's movement from one faith group to another called into play his previous experiences in order to determine his present reception and actions.

Prophet Owalo saw God and continued living, narrated his experience and wrote about it, accounts of which are analyzed above in the six chapters of the NC scriptures. Prophet Owalo's experience so inspired him that following the instructions so received to the later he founded a religious group that has outlived him based solely on the tenets of the heavenly experience he had. Prophet Owalo's experience presented in the six chapters of the NC Scriptures and in the life and practice of the NC is full indication of a community that has experienced real transformation.

Godin [93]raises four questions to test the authenticity of a personal experience of God. Prophet Owalo's experience can be gauged against Godin's four questions:

1. How much of the story is devoted to an autobiography of the author and how much to the divine encounter proper?

2. In the description given of the encounter with God, do we have solely or mainly emotional reverberations? Do we also have consequences in the life of the convert that flow from a new grasp of the divine mystery?

3. Which particular features of the divine mystery are shown in the new light? Does the author tackle it by means of a particular vocabulary or style? Is he an innovator?

4. Lastly does the story suggest a spiritual trail, an approach or method of prayer which would allow the readers, in their turn, to make some aspects of the converts experience their own? (Godin, [93,81-82]

It is true that the personal experience of prophet Owalo is presented more as a divine encounter than an autobiography of the Prophet. We see God in every step revealing himself and his plans for salvation of humankind: I am God from before and none is equal to me. But creation has turned away from me and is now worshipping fellow creatures and now I am sending you to carry aloft the Sharp Sword whoever hears let him accept but he who refuses let him be. (Sura 2) The story tells of means of accessing God and stresses severally on the commissioning to carry the pure word of God. The story is also clear that the ultimate focus of this relationship is attaining heaven the abode of God. Heaven will be accessed by some and not others; this seems to be at the discretion of God. Practices in the Roman Catholic Church that before God are contrary to God's will are clearly explicated.

In answer to the second and third question we see instances in the life of Prophet Owalo that indicate a struggle with the divine mystery. At the end of these experiences it becomes more apparent that they are new ways of looking at old experiences. Prophet Owalo's old experiences in the Roman Catholic Church will be so challenged that at the end a new Church will have been founded that is not only unique but an innovation.

In the very first instance Prophet Owalo is shocked to realize that the Pope, the Spiritual leader of the Roman Catholic faithful's is absent in heaven (Sura 1). Secondly and much more shocking is the outright refusal by Jesus Christ to allow Owalo to bow down in worship to him. Instead Jesus leads him before God where they both bow (Sura 1). Thirdly, Prophet Owalo is given the only ladder that can access the "ripe fruits" with express instructions that whoever accepts is free to use it but whoever does not accept should be left alone (Sura 2). In the fourth instance Prophet Owalo is made to realize that he has direct connection to God through the ladder: it is not to be placed on top of anything be it a creature. Prophet Owalo demonstrates his obedience by positioning the ladder in order to access the fruits. Fifthly, Prophet Owalo's ministry after commissioning is challenged: 'Why were you sent to preach the word of God yet you are preaching peoples message... you preach the pure word of God." (Sura 3)

In the sixth instance Prophet Owalo is reminded again not to worship Jesus but to worship God alone. He is told that a messenger cannot worship another messenger (Sura 4). In the seventh instance Prophet Owalo recognizes that Holy Spirit emanates from God and not from Jesus (Sura 4). In the eighth instance Prophet Owalo is told that it is not sacrifice that opens ways to God but a broken and contrite heart (Sura 4).Here like in the instance of the ripe bunch of fruit Prophet Owalo is given a long rope whose one end he holds here on earth while Jesus holds the other end in heaven 
(Sura 4). In the ninth instance Prophet Owalo is reminded not keep quiet but to preach because Jesus also preached: Jesus himself preached as shown in Matt. 18 (Sura 5).

The tenth instance shows Owalo's witness of the desire of the nations of the earth to access heaven but to their utter dismay the angels block the gate to them. However the Jews and Arabs get access and this leads the Prophet to ask why they are allowed in yet they killed Jesus. (Sura 5). The eleventh instance which is equally shocking is that the Pope in his ministry has actual blocked the way of Christ through the worship of images and relics. The twelfth issue is that the Roman Catholic mass is not the acceptable sacrifice but a broken heart. The thirteenth instance is the realization that purgatory does not exist as advocated by the Roman Catholics but only two ways; one to heaven and the other to hell.

Indeed the experience is a shattering one both in the life of the prophet and that of the reader. The reader is transported through layers and layers of new experience that at the end of the reading the reader is sure to feel exhilaration in the divine exposure. The sharing of this self-revelation of God that Owalo had written down in his own handwriting in Kiswahili and whose title was "Upanga Mkali" is enigmatic but transforming. There is, in the six episodes a clear spiritual trail that indicates the type of attitude expected of a worshipper and the duties of every adherent that are defined within the parameters of praying without ceasing and preaching in season and out of season. Every adherent must avoid the traps of religiosity that comes with creativity at the expense of being right before God.

Prophet Owalo's experience keeps its flavor of fascination to the adherents and to all who dare seek the truth that he stood for, fought for and even died as he struggled to live it. The fascination has been going on for over a centenary and it has not shown signs of waning. This study concludes that Owalo was indeed a prophet of God whose message has remained an experience of God that leads to God and Salvation. Now that the NC has a life of its own her adherents are born into this community and mature to adulthood being guided by the tenets, hopes and aspirations of the NC. Being a member of the NC is a long walk with God to God.

\subsection{Discussion of the Double Rite of Passage}

The double rite of passage is central to the $\mathrm{NC}$ as can be witnessed in a few rules and regulations of the Church. The $\mathrm{NC}$ as a religious entity developed a set of rules that defined her expectations and morals for her membership. These rules were presented to the District Commissioner in a letter dated $20^{\text {th }}$ September 1944. Bishop Eng. Olali $[70,72]$ in his book My Faith my Religion: History and Basic Doctrine of the Nomiya Church calls them the bedrock of Nomiya administrative discipline.

1. A candidate for baptism must be taught for a year before being admitted as a Christian on baptism.

2. A lay-reader must first possess the Nomiya qualification, that is baptized and circumcised and should have been trained for two years and obtained passes in religion and related subjects.

3. For one to be a priest or a Bishop in the Nomiya Church he must in the first place be circumcised.

The rules and regulation that govern and guide the practice of the double rite of passage in the NC can be viewed as products of two great pillars in the universal church that is the Church tradition and the Scriptures. The church tradition specifically the manifestations of the Christological debates in the early Church that gave rise to the doctrine of the divinity of Christ and the doctrine of the Trinity and later the corruptions of the Church of the Middle Ages that led to the call for Reformation. The Scriptures will be analyzed especially in their presentation of the covenant practices of baptism and circumcision and the attached practice of seclusion of forty and eighty days for male and female infants and their mothers respectively.

\subsubsection{Church Tradition}

For the NC, God is only one and Jesus is not co-equal with God but his messenger. This notion of God led Prophet Owalo to reject the whole concept of the Trinity. The concept of God in the NC is understood as that center around which everything is defined and understood. God is understood basically as the source of everything, transcendent and immanent; He is a God without a beginning or an end. He was not created and He would not die. He is wisdom of the wise; strength of the strong and king of kings (Lamo Mar Jehova) (Owalo [87,32-35]).

According to Archbishop Owalo Nomiya Church demands worship of God alone who is adored as all powerful and eternal. God is understood as ONE and $\mathrm{He}$ is Omnipresent, Immutable, Omnipotent, Omniscient and invisible. The church professes belief in the existence of angels, prophets and apostles including Jesus who however, is not held as God. The church holds the Scripture as sacred and looks forward to the Day of Judgment and resurrection. It believes in Heaven and Hell (Owalo [69,48]).The NC argument for God is scriptural but is further augmented by Prophet Owalo's vision in which Jesus is clearly shown as God's messenger and not God. (1Timothy 2:5-7[94]; Exodus 20: 3-5 [95) (Owalo [69,48]).

If God is one then Archbishop Owalo ([69,33]) questions the validity behind the proponents of the concept of Trinity. Agreeing with a number of scholars who argue against the doctrine of Trinity Archbishop Owalo $[(69,46])$ brings out their sentiments that the whole doctrine of Trinity is not only confusing and perplexing but also very difficult to grasp; "being beyond the grasp of human reason." Arguing that the doctrine of Trinity is false Owalo $([69,48])$ then concludes that: "Prophet John Owalo was completely right in rejecting a wrong idea, that of Trinity, which was not only mystifying the teaching of God, but also brought confusion in the minds of the adherents."

The argument for incarnation also collapses because Jesus 
is presented as a messenger. From the heavenly excursion Prophet Owalo confirmed that Jesus was a messenger like him. Jesus therefore is not God from God as the Nicene Creed states. The controversy surrounding the divinity of Christ was not something novel with the advent of the NC but what was surprising is the fact that it arose again in a church that had for over one thousand five hundred years believed it to be a foregone conclusion. Archbishop Owalo $[69,50]$ like Arius of the fourth century is convinced that Jesus was a creature but with special distinction of being God's first creation (Colossians 1:15;13-16[96], Hebrews 1:3[97]; 2 Corinthians 4:4[98]). Further Archbishop Owalo $[65,51]$ citing particularly from the infancy narratives in Matthews and Luke concludes: "that in all the above Jesus is called the son of God, not his equal or part of God himself." Reading for example from John 14:28 Archbishop Owalo $[65,37]$ continues to argue that indeed Jesus is not equal to God and Jesus never claimed to be God.

The ministry of Jesus is replete with indications of his acceptance of his inferior position. In Luke 22:42 we find a powerful example of his inferior position: “...Nevertheless, let not my will, but yours take place" Archbishop Owalo [69.37] argues that Jesus must have been addressing his prayers to someone entirely separate, his Father; God whose will was superior. Unlike God who is omniscient Jesus displayed his limitation in his lack of knowledge about the eschatological time frame. Archbishop Owalo [69,53] uses the following verse to justify his position: “...But of that day and hour no one knows, not even the angels of heaven, nor the son, but the Father only"(Matt 24:35-36).

From the foregoing the $\mathrm{NC}$ position is made much clearer that Jesus is not God Incarnate but an important person in the plan of God for salvation. On this note the doctrine of the Trinity fails in that Jesus is not co-equal with God the Father. Archbishop Owalo concludes therefore that: "From the above, the one in three gods, and three in one God is not in existence, it is a fabrication: God, son and Holy Ghost are not CO-EQUAL."(Owalo [69,55]).On the same note Archbishop Owalo [65,38] puts forward his argument against the Holy Spirit as God. He says, "The Holy Spirit is not a person and is not a part of the Trinity but God's Active Force that he uses to accomplish His will, it is not equal to God but it is always at his disposition and subordinate to Him."

The doctrine of the Trinity is widely accepted in Christendom yet still a number of Christian denominations deny it. Of these the Unitarians stand out and for this reason Prophet Owalo and his new found denomination received the label "practically a Unitarian" from the Rev. J.J.Willis. According to McGrath [49,322], the doctrine of the Trinity arose in the Church following the Christological debates in the early centuries of the Church. The relationship between God and Christ and especially in their being "of the same substance" is said to be a mystery by many scholars. The Christological debate leading to the Council of Nicaea, established the co-equality of Father and the Son, whereas the divinity of the Spirit was established in the aftermath
(McGrath [49,323]).

\subsubsection{Scriptural Basis for Circumcision}

Circumcision of both male and females are practices recognized the world over in the communities that practice them. Male circumcision is practiced by about one-third of males in the world. The two leading religious groups that practice circumcision are Islam and Judaism. Male circumcision in the NC presents itself majorly as infant circumcision and in a few cases among the mature adults.

According to the book of Genesis circumcision was first practiced by the patriarchs and it involved all males of the household (Gen.17 [7]). The OT understands circumcision as a religious rite performed on male children of Jews on the eighth day after birth (Gen. 17:12[50], Lev.12:3[51]). It was a requirement of God's covenant along with Sabbath observance and food laws. A good example is seen when Joshua had to circumcise all males who were born in the wilderness just before celebrating the Passover (Jos. 5: 2-9 [99]). Failure to observe this strict ordinance resulted in excision from the covenant community (Gen 17:14[100]).

Circumcision and obedience to the Covenant went hand in hand. The transformation of one's heart was of essential significance. God's standard that enables a harmonious relationship with his people is much more than the circumcision of the foreskin evidence in the male procreation organ. This then is the development of the understanding of circumcision as more of a spiritual requirement than a physical mark on the male body. Circumcision is not required by Judaism for one to be considered Jewish and similarly it was not required by the church for one to be considered a Christian. The first Christian Council of $49 \mathrm{AD}$ made this explicitly clear (Acts 15:28[101]).

Paul in radical shift from the traditional conception of circumcision gives it a new and significant understanding; True circumcision, he says is that of the heart, it is spiritual and not that required in written Law; it is not outward and physical. Further he notes that an uncircumcised person who is righteous is to be regarded as if circumcised. A man is not a Jew by outward appearance; the true Jew is a Jew inwardly. The circumcision made without hands also referred to as the circumcision of the heart is what counted most ( $\mathrm{Col} 2: 11[15]$; Rom 2:28-29[27]). Marshall et al $[25,121)$ argues that this circumcision of the heart is effected by the gift of the Spirit and it has rendered circumcision unnecessary (Phi. 3:3[60]; Gal. 3:3; 5:3-5[26]).

The progression and development in Paul's theology is evident in his rejection of the practice of circumcision and even out rightly condemning those who were still engrossed in the practice (Gal.3 [26]) He accused the Galatian Christians who promoted the practice as turning from the Spirit to the flesh. Paul is so infuriated by the advocates of circumcision that he accuses them of promoting the practice for individual gratification and gain. In the same vein Paul warns Christians in his letter to the Philippians to beware of the proponents of circumcision (Phil.3:2[102]). Consequently Paul identifies a true Christian as one who 
worships in the Spirit of God and who boasts in Christ Jesus and who has no confidence in the flesh as the circumcision.(Phil 3:3[60]).

Marshall [25] concludes that for Paul the Spirit had replaced circumcision as the hallmark of the covenant people. For Paul therefore the only thing that matters is faith: for in Christ Jesus neither circumcision nor circumcision counts for anything... (Gal 5:6[103]). The New Testaments conclusion that relationship with Christ sealed by baptism outweighs all other mediums of connecting with God raises the question of the continued stress and relevance of circumcision in the NC. Faith in Christ sealed in the rite of baptism seems to supersede any other marking and this thus is the essence of this study; why does the NC fall back to circumcision?

\section{6.3. Scriptural Basis of Baptism}

Christian baptism is the sacrament of initiation into life in Christ. It marks the beginning of the journey of faith and discipleship that lasts throughout one's life. In baptism a person is immersed in water, or water is sprinkled upon the person, in the Triune name of God. Authorization of baptism is often found in the command of Jesus (Matt.28:19-20[19]).Baptism is not only based on this command by Jesus but on his freewill submission to be baptized by John the Baptist. In the act of baptism Jesus enters into solidarity with the lost humanity. Baptism as a sacrament serves that very special function of enhancing cohesion and integration (Migliore [33,282]).

Baptism according to McGrath $[49,528)$ is the second major sacrament in Christianity Baptism may be understood as the rite of washing with water as a sign of religious purification and consecration (Placher [61,183]). When Nicodemus the Pharisee visits Jesus in John's Gospel Jesus tells him he must be born again. The crucifixion of Christ is the most important element of the new covenant. Entering the new covenant means being baptized into Christ's death and being raised with him into new life (Rom. 6:11 cf Col. 2:12[20]).

In the NT Jesus uses the image of baptism to relate the life of the adherents to his mission.

Baptism (going down into water and coming up out of it) in the Christian thought was related to several key events in the Old Testament that include for example: Salvation of Noah, his family and living creatures and the deliverance of Israelites across the dry bed of the dry sea (Placher, [61,184]. Migliore [33,283] says that baptism marks the beginning of the Christians participation in the life, death, and resurrection of Christ. This truth is clearly symbolized when the candidate goes down into the water (a picture of going down the grave) and coming up out of the water (a picture of being raised with Christ) and beginning a new walk in Christ (Grudem [62, 968]).

The earliest Christians according to Gonzalez did not consider themselves followers of a new religion (Gonzalez $[104,20])$. P'Bitek $[105,83]$. The Jews, the first converts to Christianity had imposed circumcision on the Gentile converts as a pre-requisite to their admission to the Christian faith (Acts 15:1-6[97]). Anderson [55:88] notes that those Gentiles who chose to be admitted into Judaism were required to be circumcised and baptized and also to keep the whole Law of Moses. This scenario gave rise to the Jerusalem Church Council of AD 49 that decided to abandon circumcision (Cross et al, [106,353]). O'Donovan [13] concurs and notes physical circumcision was then abolished and replaced with the ritual of water baptism as a necessary sign of belonging to God's covenant people(Acts $15: 1-6[107])$. In baptism the old person has to die so that the new one can be born.

The church based on scriptures has practiced believer's baptism (for those who have given reasonable evidence of believing in Christ) and infant baptism (administered to all infant children of believing parents) (Grudem, [62,969-975]). Infant baptism has continued to attract criticism over the centuries (Migliore [29, 284]; Placher, [57,186]). These arguments include first that Infant baptism has no solid biblical foundation and only became normal in the post-apostolic period and not the New Testament period and secondly that baptism is a witness to the grace of God and is a mark of the response by human to this grace (McGrath, [49,529]; Migliore, [33,284]).

The practice of baptism in the NC seems to be based on the gains made as from the times of the early Church. However its departure from the early church is based on the choice of two specific times for male and female infant baptism. On the eighth day male infants on top of baptism are circumcised; female infants are baptized on the fourteenth day. The prescription of the eighth day and fourteenth day baptism for male and female infants respectively in the NC is a novelty. The question remains why and when this departure was chosen as the path to God.

The NC understands that in performing baptism they seek the authority from God. Calling upon the name of God ensures that everything is sanctified particularly the waters of baptism. According to Archbishop Owalo [69,59-60] in calling on the name of the Father the Christians believe him to be the Father of our Lord Jesus Christ and our Father as well as our Creator, Preserver and Benefactor. Both believers (adult) and infant baptism are practiced in the NC. According to Archbishop Owalo [69,81-82] Baptism must be by immersion: Baptism by immersion is the doorway into the church. It is sacred ordinance enjoined by Christ and observed by him.

Archbishop Owalo $[69,82]$ says that the NC still practices infant baptism despite their inability to profess their faith in Christ. Archbishop Owalo follows the Anabaptist and declares that infants baptized in their infancy must be rebaptized: Thus under the Nomiya Church, it will be the responsibility of the parents and god parents to ensure that as soon as children are sufficiently prepared and ready, they are brought for confirmation. Archbishop Owalo $[69,78]$ is clear in his mind that infant baptism is a prescription from God that can only be repealed by God himself: "The ancient practice appointed by God himself, must remain a law of His 
Kingdom until repealed by the same divine authority."

From the foregoing, it is apparent that as a Christian fraternity the NC baptism carries with it the same understanding as that practiced by all other denominations. There are two outstanding differences, one is that baptism in the NC for the infants is day specific: on the eighth day for male infants and on the fourteenth day for female infants. Baptism is also done in the context of circumcision for male infants. Two is that the formula for baptism in the NC is not the triune formula (that is in the name of the Father and of the Son and of the Holy Spirit). In the NC the name of the Holy Spirit is not mentioned at all and the name of Christ is only called in the marking of the baptism candidate (Owalo $[87,56])$

\subsubsection{A Biblical Exposition of the Double Rite of Passage in the $\mathrm{NC}$}

This study understands the double rite of passage first as a covenant here expressed as 'appropriation dialogue' and secondly as a process that according to Van Gennep[108] is presented in three phases.

The double rite of passage is a concept best represented in the concept of covenant. The religious rites of baptism and circumcision affirm the divine initiative whereby God moves graciously to man in every age and time declaring his desire for fellowship. 'Appropriation dialogue' entails mutual reciprocity whereby God moves to establish a relationship with human beings and human beings in return respond in obedience. The Church is called to be a community of love and service in which all participate in an exchange for gifts given by the "gifting God" (Migliore, [33,268]). God defines the parameters of this relationship and gives the commands.

Rites of passage have the important place of creating in the initiates the story of who they are as they find the story of the community for which they are part. Rites of passage provide a window for the community to transmit its core values to the initiates thereby ensuring cultural continuity as the initiates receive the relevant instructions that define their roles and responsibilities. Van Gennep [108] identified three phases of the rites of passage: separation, liminality and incorporation. The first phase comprises detachment or withdrawal of the individual or group; while the second is an in between period that leads to the third one which involves incorporation into the society after completing the rite.

All the three stages delineated by Van Gennep are clear in the NC birth, circumcision, baptism and purification rituals. A woman who gives birth in the $\mathrm{NC}$ is expected together with the new born infant to be in a seclusion of forty days for male infants and eighty days for a female infant. During this period the rites of circumcision and baptism will be performed and at the end of the period of seclusion an elaborate service of reincorporation of the infant and the mother takes place.

\subsubsection{The Service of Cleansing of the Mother After 33/66 days (Golo or Yepo )}

The baptism and circumcision service in the $\mathrm{NC}$ are so intertwined and interconnected with the period of seclusion for the mother and child that they cannot be handled minus the service of cleansing that crowns the period of seclusion. The NC adherents are very clear about the activities that surround the baptism and circumcision. On the eighth day after birth in the morning the male infant is baptized first and then circumcised in a service that is held within the home of the parents.

A priest and the Sharif are the key officials; the godparents and parents and a congregation is of necessity present. After this service the mother and her child are to remain in seclusion for thirty three days. On the other hand the baptism of the female infant is on the fourteenth day and thereafter the mother and her infant daughter remain in seclusion for sixty six days. The adherents agree that the prescription in the texts of Lev. 12:1-8; Num.6; Gen. 17 and Lk.2 [109. then form the foundation on which the complex subject in its entirety is to be understood. In verse 3 of Lev.12 [110] the essence of this process is identified as ritual impurity: "she shall be ceremonially unclean seven days; as at the time of her menstruation...".

The central issue here then is ritual impurity. Ritual cleanliness is required to keep a person in a state of ritual purity for the purpose of performing mitzvoth commandments [12]. One who is ritually unclean was not eligible for ritual observance with a full and complete heart. This ritual impurity in birth for the woman is comparable in terms of length and quality to the impurity at the time of her menstruation. According to Dosick $[12,272]$ the Torah has a number of instances where a person comes into a state of ritual impurity that are all related to the loss of essential elements of the body; loss of bodily fluids, loss of potential life, etc.

Menstruating women are considered ritually impure because of the loss of bodily fluid are therefore ineligible to participate in the ritual observances of the Jewish people. When the monthly flow begins a woman becomes niddah (Milgrom [111]). According to Milgrom[111] the word niddah originally referred to the discharge or elimination of menstrual blood which came to denote menstrual impurity. The word niddah also came to refer to the menstruant herself for she too was discharged or excluded from the society not by being kept at arm's length from others but by being banished and quarantined in separate quarters (Milgrom [111, 745]. A state of ritual purity is reentered when one immerses in natural flowing water as a symbolic act of purification (Lev. 14:8; 15:5; 15:9; 22:6 [112] and Deut. 23:12[113]). The natural body of water can be a river, a stream, pond lake or ocean. Only then is one eligible to participate in the ritual life of the Jewish people. The water serves as a symbolic rebirth, and one emerges therefrom purified, and ready to forge ahead in a new beginning (Dosick [12,269-270]).

The mother of the newborn is to be in isolation for a total of forty days for the male child and eighty days for a female child. The circumcision and naming of the male child in the 
$\mathrm{NC}$ takes place on the eighth day while the naming of the female child is on the fourteenth day of the isolation period. During this period the NC prescription and expectation is that the:

a) The mother and child are to remain indoors and inaccessible to visitors; the woman not attending to domestic chores.

b) The woman avoids contact with any item regarded as holy; does not attend the Church service or funeral.

c) The woman and her husband have to retain separate beds for the period of isolation (Abstention).

d) At the end of the seclusion the woman and her child are cleanly shaved. The NC meets in the homestead of the isolated mother where they hold a colorful night vigil (Mony).

e) The climax is the early morning sacrifice of a chicken or a lamb which is partaken by only those who have been circumcised and by those women who have been through the period of seclusion after child birth.

\subsubsection{The Double Period of Ritual Impurity}

4.6.4.2.1 Fourteen days: This is double the period for males. The period for the ritual impurity following the birth of a girl is always longer. For the birth of a girl the mother's menstrual impurity is double that of the normal menstruation. While no exact explanation of this was found among the adherents, it is apparent that the woman has given birth to a potential mother in whom the cycle of events that surround the woman biology will be replicated in the future. Suggestions to the effect that a woman's blood flow (Nyawiwo) is heavier and lasts longer in the case of the birth of a female infant were made. However many adherents for lack of a better explanation concluded that these were prescriptions from God that require no questions but acceptance.

Baptism on the fourteenth day is a novelty unique to the $\mathrm{NC}$ because the Bible nowhere mentions it and neither does the Jewish tradition of naming choose the fourteenth day. The giving of girls names is in no way tied to the fourteenth day but is tied to the day when the Torah is read in the Synagogue. For the NC to choose the fourteenth day as the day of baptism for female infants and to put it forth as a doctrinal prescription of the church is indeed unique.

The brit milah or baby naming ceremony is always followed by a festive meal. The festive meal in the Hebrew community is a special occasion: "because it means that another precious child has been born into the Jewish community and has entered into the sacred covenant with God" (Dosick [12,290]). For the NC yet another novelty is realized here for the celebration of the child is delayed until the mother is ritually acceptable in the community of worshippers. This celebration is done on the day that the woman is purified, the very day when the woman enters the assembly of believers; the day they are welcomed hugged and showered with gifts.

\subsubsection{The Double Period of Blood Purification (Period of Seclusion)}

4.6.4.3.1 Sixty six days is also double the period of Blood Purification prescribed for the birth of a boy giving a total of eighty days before the parturient may enter the sanctuary or touch anything holy (Lev. 12:5[114]). The parturient on birth of a female infant is then considered as niddah for double the period set aside for male infants. Scholars have advanced several possible reasons: some scholars argue that the cultic inferiority of the female sex is expressed in giving the female a double 'uncleanness effect' (Milgrom [111]).The key thing is that the ritual impurity here is as a result of the loss of potential life in the loss of bodily fluid.

4.6.4.3.2 On the completion: This implies the forty first and eighty-first day. The prescribed number of days is significant and has to be observed to the letter. These numbers of days have a significant bearing to the flow of blood. In Lev 12:6,7\&8[115] we see that at the end of the specified period only then shall she bring before a priest her burnt offering and sin offering and consequently she shall be clean from her flow of blood.

4.6.4.3.3 A pair of pigeons or a pair of turtledoves. These sacrifices are brought after the impurity has totally disappeared. This prescription was meant to take care of those families that were not well to do as attested in the text of Lev. 12:8 and Lk. 2:22-24 [116]. For the NC because neither turtledoves nor pigeons exist they have instead adopted the use of chicken.

4.6.4.3.4 She shall bring: burnt offering (ola) purification offering (hattat) (Milgrom [111]). The burnt offering is necessary because it purifies the parturient.

4.6.4.3.5 The entrance of the Tent of meeting: The active agent in the purification service is the new mother. The priest is merely the passive recipient, awaiting her and her offerings in the sanctuary. The woman brings the offertory to the entrance of the Tent of Meeting to the priest. The priest will offer them. Because the NC has adopted the Nazirite prescription and ascribe the same to the woman who is to be purified we find here that a basket of unleavened bread (for the NC Chapat) is also offered. This together with the chicken that has been roasted will be taken by the priest and those who are eligible as a purification meal (Num. 6:19 [117]). It is from this scripture portion that the concept of shaving of the woman's and child's head is lifted to the Levitical prescription. The shaving of the mother and the child's head on the eve of the purification is again a novelty in the NC.

4.6.4.3.6 And then she shall be pure" Now that the forty days (or eighty days) have elapsed and she has brought her requisite sacrifices to the sanctuary, she is purified and is eligible to make contact with sacred objects.

4.6.4.3.7 The priestly Benediction: From the Book of Numbers comes another unique feature that has become part of the purification service, the benediction (Num.6:24-26[118]). The benediction is a blessing 
pronounced in this case to the couple and their child as they enter back into the larger community; and this marks the time of their rebirth. The reunion of new initiates with their family and community is a collective festive time; all rejoice now that the new initiates are ready to assume their new place in the community.

\subsection{Conclusions}

The NC stands unique on two premises, one as the first African independent church in Kenya; and the first Independent Church in Kenya to start secular education for her members (Ndeda [36] Ogot [72]) and secondly as the only Christian body in Kenya that does circumcision as a religious ritual simultaneously with baptism. The second aspect has not been documented although there is a lot of literature on Johana Owalo and his new movement.

The NC is indeed an Ethiopic or nationalistic AICs due to the fact that it is both a breakaway group from the missionary-led churches, and also a protest group against missionary paternalism and colonial oppressive structures. Due to irreconcilable doctrinal difference that were actually fuelled by the missionary paternalism and colonial oppressive structures the NC broke away from a missionary-led church. Prophet Johana Owalo is in this respect referred to as the first Christian rebel.

The double rite of passage is an elaborate service that goes beyond the Jewish circumcision and naming ceremony bringing in the Nazirite vows and the Christian baptism together all to be crowned by the ceremony of completion of the blood purification rites. For male infants the service starts with the Christian baptism done by a priest followed by circumcision done by Sharif, after which the church confines the woman and the child for thirty three days. At the end of this period the church comes together in a service that begins with the shaving of both the mother and the child to mark the end of their confinement, an overnight vigil (Mony), an early morning sacrifice and meal for the cleansing of the woman that climaxes in a welcome and readmission service in the church led by Simeon-Ka-Lawi.

Female infants though excluded from the double rite of passage bring in another novelty of baptism on the fourteenth day. The fourteenth day coincides with the biblical prescription of the doubles that a woman on the birth of a female will undergo separate and different from those on the birth of a male: the Double Period of Ritual Impurity (she shall be unclean for fourteen days as in her menstruation); and the Double Period of Blood Purification or Confinement (Her time of blood purification shall be sixty-six days). The parturient in the NC unlike their Jewish counterparts will be following the Nazirite regimen of prescription that are much stricter including total avoidance of funerals even of the closest of relatives, avoidance of intoxicants and keeping of the hair unshaved all in dedication to God.

This study has shown that the practice of circumcision and baptism in the NC is the one original prescription by Johanna
Owalo the founder that has retained the initial design and intentions. In comparing the liturgy of worship in the secessionist groups and those of the NC it was apparent that the double rite of passage in its details is common to all the groups. The NC can be said therefore to have retained the initial teaching on the double rite of passage which has remained unaffected by the pressures and exigencies of life. Jewish origins for circumcision on the eighth day cannot be disputed. The influence of Owalo's visions particularly in inaugurating a new way of looking and understanding an old Jewish prescription cannot be overlooked.

In the $\mathrm{NC}$ scripture the fact that Owalo was directed to carry the sharp sword has been taken by many as having a direct correlation to circumcision. Owalo also gets the privilege and advantage over others when the angel Jibraeli offers him a ladder that enables him to reach the ripe fruit while directing him to throw away all the rest in order that they break. Owalo's ladder is the only ladder that is to be used and whoever chooses not to use this ladder will not be compelled to do so. Similarly, Owalo has the special advantage of being the one to whom a long rope is offered. Owalo holds the end of the rope here on earth while Jesus holds the other end in heaven.

This direct connection now argues strongly against other media of reaching God other than through the way of Jesus. The concept here of the ripe bunch of fruits and that of the long rope tip the scale more towards an emphasis on the word of God as the essence of the sharp sword.

Just because the practice of circumcision was a novelty among the Luo People, the sharp sword was for a long time understood only as it related to circumcision. A number of adherents still see the sharp sword only in this manner. For them salvation is through circumcision and whoever is circumcised in the flesh as the law stipulates has booked himself a place in heaven. However as one moves across the NC Diocese now there is a strong movement that now holds and preaches that the sharp sword is nothing more than the word of God. This Word they are now connecting to Jesus Christ and to salvation. The salvation movement is gaining momentum.

Baptism on the other hand and especially infant baptism seemingly has no documented evidence of being done on the eighth day or even on the fourteenth day. The examples above support the uniqueness of the practice by the NC. Circumcision and baptism on the eighth day for male infants and baptism on the fourteenth day for female infants seems peculiar to NC. In the Jewish rite of passage, brit milah boys are given names at the ceremony done at home while girls are given their Hebrew names at the synagogue. From the foregoing it is apparent that naming of girls in the Hebrew culture was not connected to the fourteenth day and could fall on the various days when the Torah was to be read in the Synagogue. On the other hand the earlier practice was not an at-home practice but it is increasingly becoming one in order to give the newborn baby girl an equal celebration with the newborn baby boy. This is an affirmation that the baptism of 
a girl on the fourteenth day is a novelty having neither a Jewish background nor a Christian background because baptism in the Christian Church has never been a day-specific event.

The baptism of Jesus takes place at about thirty years of age. Jesus then is the prototype of the circumcision/baptism. He was circumcised and named on the eighth day according to Jewish customs (Lk. 2:21[119]).Jesus like all true Jews carries the mark of the covenant on his flesh. However at about age thirty when he was just about to inaugurate his ministry he was baptized in the River Jordan by John the Baptist. Paul, the apostle is a good example of what every Jewish convert went through; he was baptized after he met the risen Lord (Acts 9:18[120]). Later the first converts who were Jews and whose males had been circumcised on the eighth day were also baptized as a sign that they had been united with Christ and were now members of the body of Christ This self-same prescription they desired of the Gentile converts, and were ready to enforce (Acts 15:1[121]). This issue was hotly debated and eventually became the core issue in the Jerusalem Council of AD 49. The Councils decision was that circumcision would no longer be a requirement for conversion. Seemingly the first Church Council decided for Baptism rather than circumcision and for more than eighteen centuries most of Christendom accepted and propagated that the entry requirement for Christian membership was baptism. Infant baptism was equally accepted despite the many controversies that continued to plague its practice.

Circumcision and baptism practiced together was a rare practice and was only found in a few Christian churches that somehow had a very strong Jewish background for example: The Ethiopian Orthodox Church, the Coptic orthodox and Eritrean Orthodox Church. This study has demonstrated that the double rite of passage of circumcision and baptism in the $\mathrm{NC}$ and especially in its mode of execution is a novelty. Baptism and circumcision on the eighth day for male infants and baptism on the fourteenth day is a novelty.

In view of the foregoing it can be said that Prophet Owalo brings to the surface issues that the Church imagined it had dealt conclusively with. It is worth noting that the heavenly excursion in which Jesus identifies himself as a messenger seems to hand to Arius an affirmation of what the Niceno-Constantinopolitan Councils denied him and even excommunicated him for.

The NC is first a Christian denomination which like many African initiated churches has chosen an Old Testament practice or an African heritage practice or many and which they have so blended together in order to yield a practice that is authentically African. The choice of circumcision and baptism that have roots in the Jewish tradition and giving them specific days for their performance have inaugurated a new practice from the perspective of Judaism and Christianity. Giving the double rite of passage the flavor of an elaborate ritual and celebration at the end of the forty and eighty days of seclusion has given birth to a unique religious ritual in the NC.

That the coloring and flavor in these rituals that have their origins in Judaism and Christianity can be argued to be means through which the NC expressed and asserted her Africanness in the face of the oppressive missionary enterprise and white hegemony. The success of the NC can be identified in the enrichment of the African expression of Christianity effectively and more particularly in the ongoing process of emancipating Christian thought and praxis from domination by European concepts and values. In the NC three areas stand out and they are hybrid practices that effectively demonstrate her uniqueness; these include: circumcision and baptism, polygamy and leviratic marriage and burial rites. For the NC the rites of circumcision and baptism have now become a tradition and are understood as rites of admission into the body of Christ and a sign of the seal of the covenant relationship between God and his people.

This is the NC Christian identity that cannot be varied. Baptism can be done without circumcision but circumcision will always be done after baptism. A number of $\mathrm{NC}$ adherents for one reason or another may choose only baptism and not circumcision for themselves or their children. Although members, the uncircumcised are limited in their participation in the following ways: they will never be priests or leaders in the church until they are circumcised, they cannot step on the altar area; and they are not allowed to partake of the sacrificial meal of the newly made full members of the church.

Looking at the practice of the double rite of passage in the $\mathrm{NC}$, it is apparent that it is baptism that is first done followed by circumcision. Baptism still maintains its universal character in that females are enjoined in this ritual. Choosing Christ is choosing the path of salvation. The reasons for the choice of circumcision can be fully understood from its Jewish tradition root as a covenant marker that distinguishes God's people from the others. Its choice together with polygamy and levirate marriage may be argued to be means of promoting and propagating the Jewish religion and its patriarchal tendencies. However the fact that they have been given a different flavor suggests in essence that the NC in these practices was actually rejecting the missionary view of Christianity and the oppressive missionary enterprise.

\section{REFERENCES}

[1] Nthamburi, Z. The church at the crossroads (In Crouch, M.(ed). A vision of Christian mission: Reflections on the Great Commission in Kenya 1943-1993 p169-178) . Nairobi: NCCK;1993.

[2] Taylor, J.V. Christian presence amid African religion. Nairobi: Acton Publishers;2001.

[3] Mbiti. J.S. African Religion and Philosophy Mbiti, J.S. Nairobi: Heinemann;1969.

[4] Mugambi, J.N.K. Christianity and African culture. 
Nairobi:Acton Publisherd;2002.

[5] Brueggemann, W. An introduction to the Old Testament: The Canon and Christian imagination. Louisville: Westminster John Knox Press; 2003.

[6] Exodus 19:3b-8

[7] Levenson, J. Sinai \& Zion: An entry into the Jewish Bible. New York :HarperSanFransisco Publishers; 1985.

[8] Exodus 6:7

[9] Jeremiah $11: 4 ; 24: 7 ; 30: 22$

[10] Ezekiel 11:20; 14;11

[11] Genesis 12:7-11

[12] Dosick, Rabbi Wayne. Living Judaism: The complete guide to Jewish belief, tradition and practice, New York: HarperSanFrancisco; 1995.

[13] O'Donovan, W. Biblical Christianity in African perspective ( $2^{\text {nd }}$ Rev..Ed.). Carlisle, UK: Paternoster Press; 1995.

[14] Deuteronomy 10:6

[15] Colossians 2:11

[16] Jeremiah 4:4; 9:26

[17] Jeremiah 31:31

[18] Matthew 26:26-28

[19] Matthew 28:19-20

[20] Romans 6:11 cf Colossians 2:12

[21] 1 Cor. 7:19

[22] Romans 6:1-4

[23] Colossians 2:11-12

[24] Acts of the Apostles 2:28

[25] Marshall et al. New Bible Dictionary $\left(3^{\text {rd }}\right.$ ed $)$. Downers Grove, Illinois: Intervarsity Press; 1996.

[26] Galatians 3:3; 5:3-5

[27] Romans 2:18-29

[28] 2 Corinthians 3:3-6

[29] Jeremiah 31:31-34

[30] 2 Cor. $1: 22$

[31] Acts of the Apostles 2:38

[32] Mark 16:16

[33] Migliore, D. Faith seeking understanding: An introduction to Christian Theology. $2^{\text {nd }}$ Edition. Michigan: William B. Eerdmans Publishing company; 2004.

[34] Leviticus 11:44

[35] Deuteronomy 30:15-19

[36] Ndeda M.A.J. “The Nomiya Luo Church: A gender analysis of the dynamics of an African independent church among the Luo of Siaya" Gender, Literature and Religion in Africa: CODESSRIA Gender Series 4, Dakar, Senegal: Council For the Development of Social Science Research in Africa; 2005.
[37] Mwaura P. p102 (in Mugambi, J.N.K and Getui, M.N. Religions in eastern Africa under globalization. Nairobi: Acton Publications. 2004).

[38] Nthamburi, Z. (Ed). From Mission to Church: A handbook of Christianity in East Africa. Nairobi: Uzima Publishing House; 1995.

[39] Wipper, A. Rural rebels: A study of two protest movements in Kenya. London; Oxford University Press; 1977.

[40] Isichei, E. A history of Christianity in Africa: From antiquity to the present. Grand Rapids, Michigan: William B. Eerdmans Publishing House; 1995.

[41] Ogutu, G. E. "Culture and Language in the God Talk" Robert P. Scharlemann and Gilbert E.M. Ogutu (Editors), God in language. New York: Paragon House Publishers; 1987.

[42] Achieng,' J. Paul Mboya's Luo Kitgi Gi Timbegi: A translation into English. Nairobi: Atai Joint Limited 2001.

[43] Ongong'a, J. Life and death- A Christian/Luo dialogue: Spearhead No.78 Eldoret: Gaba Publications; 1983.

[44] Odinga, O. Not yet uhuru: An autobiography. Nairobi: Heinemann Educational Books; 1967.

[45] Ogot, B.A. A History of the Luo-Speaking Peoples of Eastern Africa. Kisumu: Anyange Press Ltd 2009.

[46] Lonsdale, J.M. A political history of Nyanza 1883-1945.Dissertation 1964

[47] Kitap Ligangla Mabith

[48] Genesis 17

[49] McGrath, A. E. Christian Theology: An introduction. (3rd Ed.). Malden, MA: Blackwell Publishers Inc; 2001.

[50] Genesis 17:12

[51] Leviticus 12:3

[52] Genesis 17:10-17

[53] Exodus 12:44

[54] Exodus 12:48

[55] Genesis 34:14-16

[56] 1 Samuel 14:6; 21:4

[57] Anderson, K. B. The theology of the Bible: Theological education by extension book 2 Nairobi: Evangel Publishing House; 1983.

[58] Acts of the Apostles 15:1-29

[59] Philippians 3:3

[60] Placher,W. Jesus the savior; The meaning of Jesus Christ for Christian faith. Louisville, Kentucky: Westminster John Knox Press;2001.

[61] Grudem, W. Systematic theology: An introduction to Biblical doctrine. Leicester, England: Inter Varsity - Press; 1994.

[62] Kothari, C.R. Research methodology: Methods and techniques(2nd Rev.Ed.). New Delhi: New Age International (P) Ltd., Publishers; 2004.

[63] Peter, C. A guide to academic writing. (10th Reprint). Eldoret: Zapf Chancery. 2010. 
[64] Rarieda District Development,2008-2012

[65] Kenya Population and Housing Census, 2009

[66] Opwapo, M.A .Nomiya Luo Church: The dynamics of an African Independent Church among the Luo of Siaya District. Unpublished MA Thesis University of Nairobi; 1981.

[67] The Rev. Andrew Nyanya

[68] Owalo, G.C. The Father is Greater than I am.(Unpublished)

[69] Olali, C,L. My faith my religion: History and basic doctrine of Nomiya Church; 2015.Nairobi:Juem Agencies.

[70] Burgman, H. The way the Catholic Church started in Western Kenya. Nairobi: Mission Book Service; 1990.

[71] Ogot, B.A. Zamani: A Survey of East African History.East African Publishing House Nairobi; 1974.

[72] Kitap Lamo, Wende Sabato, Kod Wende Mag Mony Mag Nomiya Church

[73] Kateregga, B.D.\& Shenk D.W. Islam and Christianity: A Muslim and a Christian dialogue. Nairobi: Uzima;1980.

[74] Gale, H.P.. Uganda and the Mill Hill Fathers. London: Macmillan and Co Ltd; 1959.

[75] Judicial 1/297

[76] KNA/474

[77] Macpherson, R. The Presbyterian church in Kenya: an account of the origins and growth of the Presbyterian church of East Africa. Nairobi: the Presbyterian Church of East Africa; 1970.

[78] Bishop Enoka Agedi

[79] Acts of the Apostles 1:8

[80] Ochola-Ayayo, A.B.C. Traditional ideology and ethics among the Southern Luo. Uppsala, Sweden: Scandinavian Institute of African Studies;1976.

[81] Elizabeth, C. Fifty years in Nyanza 1906-1956: The history of the CMS and the Anglican Church in Nyanza Province. 1956.

[82] Uganda Notes

[83] Barrett, D. B. Schism and renewal in Africa: An analysis of six thousand contemporary religious movements. Nairobi: Oxford University Press; 1968.

[84] Maxon, R.M.. John Ainsworth and the making of Kenya. University Press of America; 1980

[85] Mugambi, J.N.K. African Christian Theology: An introduction. Nairobi: Heinemann

[86] Kenya; 1989.

[87] [Owalo, G.C. Kitap lamo mar Nomiya Church. Nakuru: Gesuma Printers; 2010.

[88] Acts of the Apostles 9:15

[89] Deuteronomy 18:18

[90] Deuteronomy 18:21-22
[91] Isaiah 55:10-11

[92] Romans 10:17

[93] Godin, A. The psychological dynamics of Religious experience. It doesn't fall down from Heaven. Birmingham, Alabama: Religious Education Press; 1985.

[94] 1 Timothy 2:5-7

[95] Exodus 20:3-5

[96] Colossians 1:15; 13-16

[97] Hebrews 1:3

[98] 2 Corinthians $4 ; 4$

[99] Joshua 5:2-9

[100] Gen 17:14

[101] Acts 15:28

[102] Philippians 3.2

[103] Galatians 5:6

[104] Gonzalez, J. The story of Christianity. Vol. 1: The early Church to the dawn of the Reformation. New York: HarperSanFransisco; 1984.

[105] p'Bitek, O. African religions in Western Scholarship. Nairobi: Kenya Literature Bureau; 1970.

[106] Cross, F.L. and Livingstone, E.A. (Eds). The oxford dictionary of the Christian Church. New York: Oxford University Press; 1997.

[107] Acts 15:1-6

[108] Van Gennep, A. The rites of passage. Translated by Monika B. vizedom and Gabrielle L. Caffee. Chicago: The University of Chicago Press; 1960.

[109] Lev.12:1-5; Num.6;Gen. 17,Lk.2

[110] Lev.12:3

[111] Milgrom, J. Leviticus 1-16: A new translation with introduction and commentary (The Anchor Bible). New York: Doubleday Publishers; 1991.

[112] Lev $14: 8 ; 15: 5 ; 15: 9 ; 22: 6$

[113] Deut. 23:12

[114] Lev. 12:5

[115] Lev 12:6,7\&8

[116] Lev. 12:8 and Lk. 2:22-24

[117] Num. 6:19

[118] Num.6:24-26

[119] Lk. 2:21

[120] Acts 9:18

[121] Acts 15:1 